\title{
CONTAGEM DE CÉLULAS SOMÁTICAS E CARACTERISTICAS PRODUTIVAS DE VACAS EM LACTAÇĀO DA RAÇA HOLANDESA
}

\section{Alfredo Ribeiro PEREIRA}

Engenheiro Agrônomo

Orientador: Prof.Dr. PAULO FERNANDO MACHADO

Dissertação apresentada à Escola Superior de Agricultura "Luiz de Queiroz", Universidade de São Paulo, para obtenção do título de Mestre em Agronomia, Área de Concentração: Ciência Animal e Pastagens.

\section{PIRACICABA}

Estado de São Paulo - Brasil

Abril - 2000 


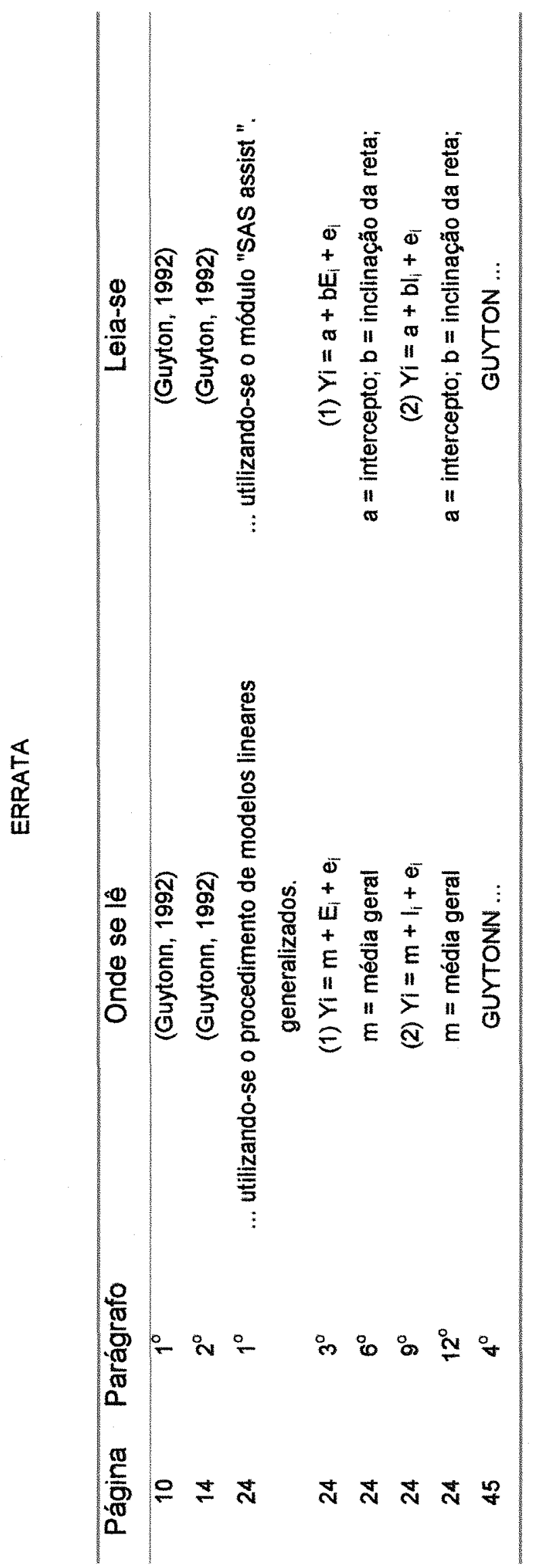




\section{Dados Internacionais de Catalogação na Publicação (CIP) DIVISÃo DE BIBLIOTECA E DOCUMENTAÇÃO - Campus "Luiz de Queiroz"/USP}

Pereira, Alfredo Ribeiro

Contagem de células somáticas e características produtivas de vacas em lactação da raça holandesa / Alfredo Ribeiro Pereira. - - Piracicaba, 2000.

$53 \mathrm{p}$.

Dissertação (mestrado) - Escola Superior de Agricultura Luiz de Queiroz, 2000. Bibliografia.

1. Célula somática 2. Desempenho animal 3. Fisiologia animal 4. Lactação animal 5. Mastite 6. Vaca holandesa 7. Vaca lactente I. Título

CDD 636.234 


\section{Dedico}

Aos meus pais, Heliane e José Alfredo,

As minhas irmãs Cláudia, Thereza Cristina e Camila

E em especial ao meu avô Gabriel Ferraz Ribeiro a

quem devo o amor pelas coisas da terra.

\section{OFEREÇO}

A Ivane Graciano Ribeiro. 


\section{AGRADECIMENTOS}

A ESALQ/USP, pela formação pessoal e profissional, Ao CNPq, pela concessão da bolsa de estudo.

Ao Prof. Dr. Paulo Fernando Machado, pela orientação e formação profissional.

Ao Prof. Dr. Raul Dantas D'Arce, pelas valiosas sugestões feitas a dissertação.

Ao Prof. Dr. Gabriel Adrián Sarriés, pelo auxílio nas análises estatísticas.

Aos colegas de pós-graduação, pela amizade e apoio, em especial para Elaine Patrícia, Sérgio Raposo e Luiz Felipe.

Aos amigos do Departamento de Produção Animal da ESALQ (em especial, Cristiane, Dionete, Fabiana, Camila, Andréia, João), a todo seu corpo técnico e de pesquisadores, por esses anos de convivência.

A todos os professores do Curso de Ciência Animal e Pastagens, pelos ensinamentos recebidos.

Aos colegas da república Atecubanos, pelo apoio cultural nas horas de folga.

A todos os que me apoiaram, e desejaram que eu atingisse o meu objetivo, 


\section{Epígrafe}

"Deve-se, ou se aprendendo de outro, ou por investigação própria, tornar-se conhecedor do que não se conhece. O que é aprendido, pois, (vem) de um outro e por auxílio alheio; o que é investigado (vem) da própria pessoa e por auxilio próprio; encontrar sem procurar (é) difícil e raro, mas, procurando, é acessível e fácil; se não se tem conhecimento é impossível procurar" Arquitas de Tarento* Cerca de 400-365 A.C.

"E realmente tudo que é conhecido tem número; pois nada é possível pensar ou conhecer sem ele" Filolau de Crotona* Meados do século V A.C.

*filosofos pré-socráticos da escola pitagórica 


\section{SUMÁRIO}

Página

LISTA DE FIGURAS …................................................................ vii

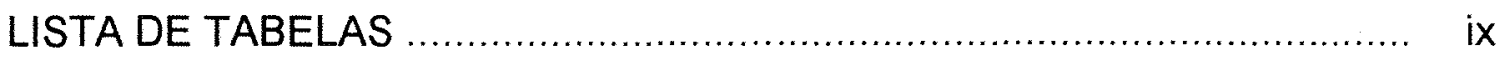

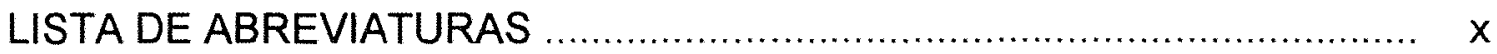

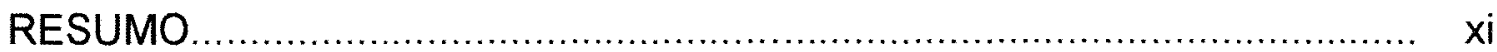

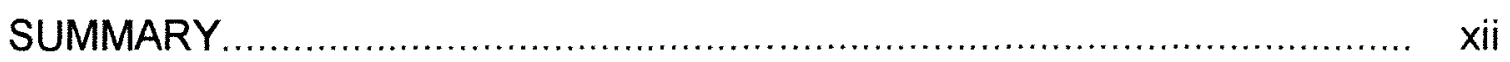

1 INTRODUÇÃO

2 REVISÃO DA LITERATURA ............................................................. 3

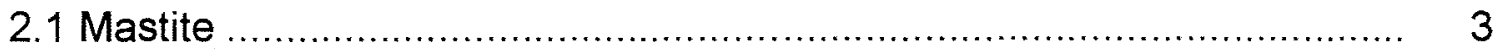

2.2 Contagem de células somáticas .................................................... 4

2.2.1 Neutrófilos polimorfonucleares .................................................... 5

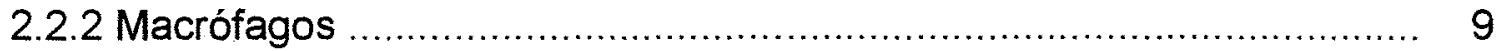

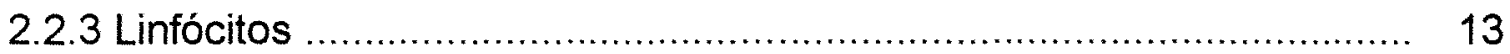

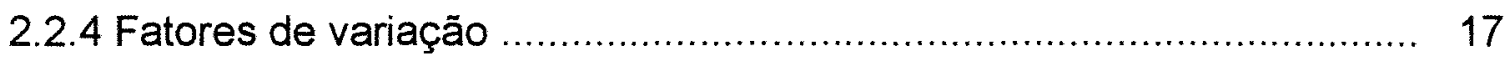

2.2.4.1 Sanidade da glândula mamária ................................................... 17

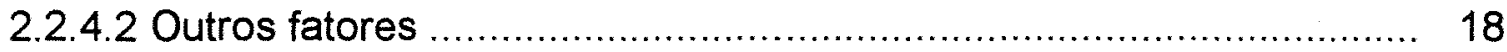

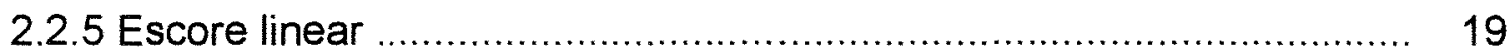

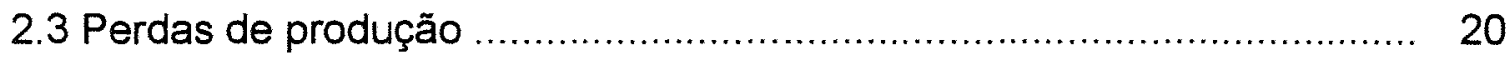

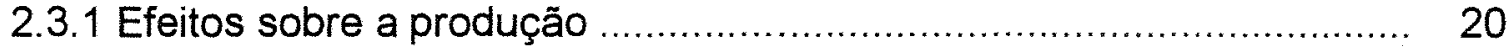

2.3.2 Estimativa da perda de produção .............................................. 21

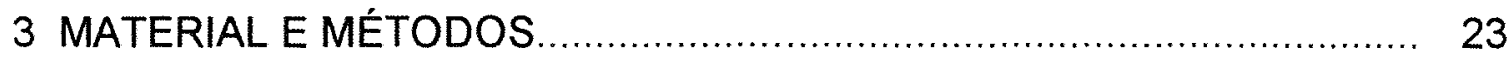

4 RESULTADOS E DISCUSSÃO....................................................... 25

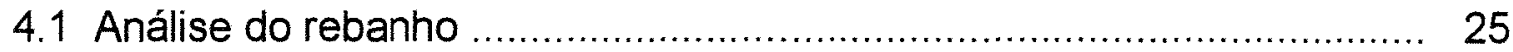

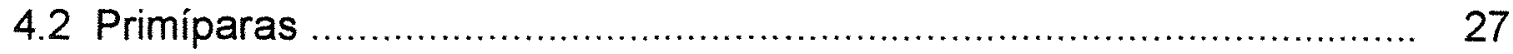

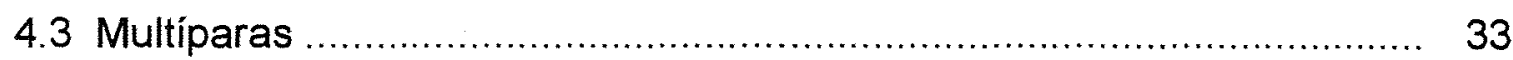

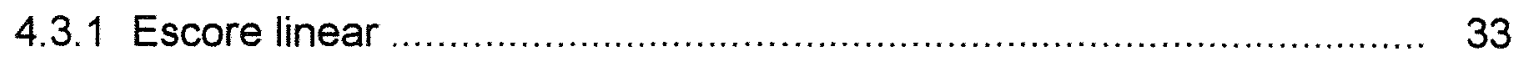

4.3.2 Número de lactações ................................................................. 38

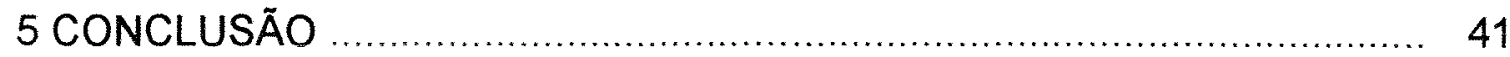

REFERÉNCIAS BIBLIOGRÁFICAS ................................................. 42

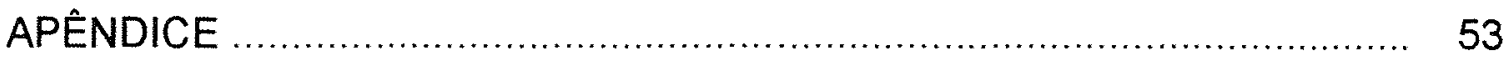




\section{LISTA DE FIGURAS}

Página

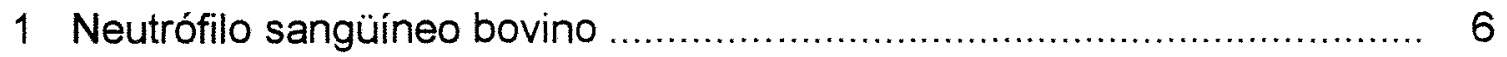

2 Neutrófilos com fagossomos contendo gordura e caseína ..................... 9

3 Macrófago com um grande fagossomo com conteúdo desconhecido ...... 10

4 Pedaços da mucosa intestinal mostrando as Placas de Peyer .............. 14

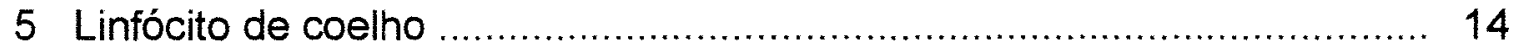

6 Distribuição dos dados de EL das primíparas .................................... 28

7 Produção de leite $(\mathrm{Kg})$ em 305 dias em lactação em função do escore linear médio da lactação (EL) dos animais primíparos ......................... 29

8 Efeito do EL médio da lactação sobre a PG305 (Kg) transformada para

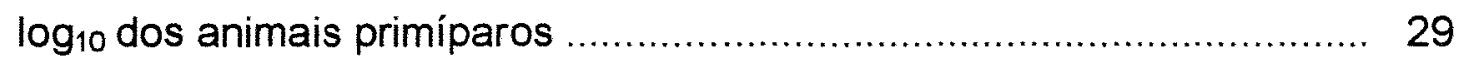

9 Efeito do EL médio da lactação sobre o inverso da duração da lactação dos animais primíparos ................................................................... 30

10 Distribuição dos dados de MEDINI das primíparas .............................. 31

11 Efeito do EL médio do início da lactação (MEDINI) sobre a produção de leite no pico de lactação $(\mathrm{Kg})$ dos animais primíparos

12 Efeito do EL médio do início da lactação (MEDINI) sobre a data de ocorrência do pico de lactação (dias) dos animais primíparos

13 Produção de leite $(\mathrm{Kg})$ em 305 dias em lactação em função do escore linear médio da lactação (EL) dos animais multíparos

14 Produção de gordura $(\mathrm{Kg})$ em 305 dias em lactação em função do escore linear médio da lactação (EL) dos animais multíparos

15 Duração da em lactação (transformado para $\log _{10}$ ) em função do escore linear médio da lactação (EL) dos animais multíparos

16 Produção de leite no pico em função do escore linear médio do início da lactação dos animais multíparos

17 Data de ocorrência do pico de produção (transformada para seu inverso) em função do escore linear médio do início da lactação dos 
animais multíparos

18 Produção de leite em 305 dias de lactação em função do número de lactações dos animais multíparos

19 Produção de leite no pico de lactação em função do número de lactações dos animais multíparos

20 Resultado de cultura microbiológica de 93 amostras de leite colhidas em animais que apresentaram alteração da condutividade elétrica do leite (APÊNDICE) 


\section{LISTA DE TABELAS}

Página

1 Porcentagem dos diferentes tipos de células de defesa no interior da glândula mamária não infectada nos diferentes estados fisiológicos ....

2 Relação média entre os linfócitos T CD4 e CD8 no sangue e secreção mamária durante a lactação ........................................................ 15

3 Valores de CCS transformados e os patógenos da mastite ............... 17

4 Médias e índices de dispersão dos dados originais de produção de leite e gordura em 305 dias de lactação, duração da lactação, produção de leite no pico, escore linear médio durante a lactação e média do escore linear durante o início da lactação de primíparas e multíparas.

5 Resumo da análise de regressão do efeito do escore linear médio da lactação sobre a produção de leite e gordura em 305 dias em lactação, sobre a duração da lactação, e efeito escore linear médio do inicio da lactação sobre a produção de leite no pico e a data do mesmo em primíparas

6 Resumo da análise de regressão do efeito do escore linear médio da lactação sobre a produção de leite e gordura em 305 dias em lactação, sobre a duração da lactação, e efeito escore linear médio do inicio da lactação sobre a produção de leite no pico e a data do mesmo em multíparos

7 Resumo da análise de variância do efeito do número de lactações sobre a produção de leite em 305 dias em lactação, e sobre a produção de leite no pico em multíparos 


\section{LISTA DE ABREVIATURAS}

$\mathrm{ACTH}=$ hormonio adrenocorticotrófico

CCS = contagem de células somáticas

CMT = "California mastitis test"

$\mathrm{CV}=$ coeficiente de variação

$\mathrm{DHI}=$ "dairy herd improvement"

$\mathrm{DL}=$ duração da lactação

$\mathrm{DP}=$ data do pico de lactação

$E L=$ escore linear

$\mid \mathrm{MI}=$ infecção intramamária

MEDINI = média do escore linear no início da lactação

NK = "natural killer"

PG305 = produção de gordura em 305 dias em lactação

$\mathrm{PICO}=$ produção de leite no pico

PL305 = produção de leite em 305 dias em lactação 


\title{
CONTAGEM DE CÉLULAS SOMÁTICAS E CARACTERISTIICAS PRODUTIVAS DE VACAS EM LACTAÇÃO DA RAÇA HOLANDESA
}

\author{
Autor: ALFREDO RIBEIRO PEREIRA \\ Orientador: Prof. Dr.: PAULO FERNANDO MACHADO
}

\section{RESUMO}

Este estudo foi realizado com o objetivo de se quantificar o efeito do nivel de células somáticas, transformado para escore linear (EL), sobre a produção de leite e gordura em 305 dias de lactação (PL305, PG305), produção de leite no pico (PICO) e duração da lactação (DL) de bovinos da raça holandesa.

Foram levantadas, no banco de dados do Laboratório de Fisiologia da Lactação da ESALQ - USP, informações referentes a 147 lactações encerradas de vacas da raça holandesa ( 83 primíparas e 64 multíparas), de um rebanho confinado do Estado de São Paulo.

As análises estatísticas foram realizadas no pacote estatístico SAS, utilizando-se o procedimento de modelo lineares generalizados.

Contrariando a literatura, as características produtivas dos animais primíparos não sofreram efeito significativo do escore linear. Provavelmente este fato ocorreu devido a quase inexistência de animais primíparos com $E L$ maior que 4,5 .

O aumento do escore linear médio durante a lactação resulta em diminuição da produção de leite e gordura em 305 dias de lactação. 0 aumento do escore linear médio durante o início da lactação resulta em diminuição da produção de leite no pico da lactação.

Considerando-se que os rebanhos analisados pelo Laboratório de Fisiologia da Lactação apresentam, em média, 121 vacas em lactação a redução de apenas uma unidade de EL corresponderia a um aumento de 38115 $\mathrm{Kg}$ de leite e $1543 \mathrm{Kg}$ de gordura em 305 dias de lactação para cada rebanho. 


\title{
SOMATIC CELLS COUNT AND PRODUCTIVE CHARACTERISTICS IN LACTATING HOLSTEIN COWS
}

\author{
Author: ALFREDO RIBEIRO PEREIRA \\ Adviser: Prof. Dr. PAULO FERNANDO MACHADO
}

\section{SUMMARY}

The objective of this study is to quantify the effect of the levels of somatic cells, transformed into linear score (LS), in the production of milk and fat in 305 days of lactation (PL305, PG305), peak milk production (PEAK) and the lactation duration time (LD) of Holstein cattle.

Information concerning 147 closed lactations of Holstein cows (83 primiparous and 64 multiparous) from a confined herd in the state of São Paulo were collected from the data bank of the Lactatio Physiology Laboratory at ESALQ-USP.

Statistical analyses were performed in the SAS statistical package through the generalized linear model procedure.

On the contrary of the literature, the productive characteristics of primiparous have not gone through a significant effect in the linear score. Probably, this fact took place due to the almost non-existence of primiparous with a LS larger than 4.5 .

An increase in the average linear score during lactation results in the decrease of fat and milk production in 305 days of lactation. The increase in the average linear score in the beginning of the lactation period results in the decrease of milk production in the peak of lactation.

Considering that the herds analyzed by the Lactation Physiology Laboratory present, on average, 121 lactating cows, the reduction of only one LS unit would correspond to an increase of $38115 \mathrm{~kg}$ of milk and $1543 \mathrm{~kg}$ of fat in 305 days of lactation for each herd. 


\section{INTRODUÇÃO}

A mastite é um processo inflamatório da glândula mamária acompanhado da redução de secreção de leite e mudança de permeabilidade da membrana que separa o leite do sangue. Normalmente é causada pelo desenvolvimento de microrganismos, principalmente bactérias, no interior da glândula mamária (Machado et al., 1998).

Vários levantamentos realizados, no Brasil, de 1970 até hoje apontam alta incidência desta doença, com índices variando de $11,9 \%$ a $58,8 \%$ de vacas infectadas por rebanho (Langenegger et al., 1970; Nader Filho et al., 1985; Laranja \& Machado, 1994).

Esta doença é considerada a mais custosa para a atividade leiteira por alguns autores. Estima-se que as perdas econômicas mundiais causadas por ela chegam a 35 bilhões de dólares por ano e nos EUA os prejuízos anuais seriam de 2 a 4 bilhões de dólares (Polititis et al., 1995; Giraudo et al., 1997). No Brasil não existem estatísticas confiáveis, mas estima-se que as perdas sejam grandes.

Além da produção de leite, outras características produtivas como a produção de gordura e a duração da lactação também são afetadas (Machado et al., 1993; Gadini et al., 1997b; Norman et al., 1999).

As perdas econômicas associadas a mastite variam de 160 a 344 dólares por vaca em lactação. A perda de leite é o principal prejuízo associado a mastite, correspondendo a cerca de 70 a $85 \%$ dos prejuízos totais (Morin et al., 1993).

Os efeitos da mastite na performance das vacas leiteiras não são 
facilmente quantificados pois existe grande variabilidade na resposta da produção de leite em relação a mastite (Lescourret \& Coulon, 1994).

Estas variações são devidas a diferenças nas populações estudadas, aos indicadores da mastite e ao método estatístico utilizado (Hornet et al., 1999).

Diferentes métodos tem sido utilizados para o estudo dos efeitos da mastite sobre a produção, um deles é o estudo da alteração da produção em 305 dias em lactação associada ao aumento da média da contagem de células somáticas (CCS) ou de sua função log durante a lactação (Raubertas \& Shook, 1982; Hornet et al., 1999).

Células somáticas são células da vaca presentes no leite. Normalmente são células de defesa ( leucócitos) do organismo que migram do sangue para o interior da glândula mamária com o objetivo de combater agentes agressores, mas também podem ser células secretoras descamadas. Esta migração de leucócitos é resultado da ocorrência da mastite (Machado et al., 1999).

O objetivo deste trabalho é quantificar o efeito do nível de células somáticas, transformado para escore linear, sobre a produção de leite e gordura em 305 dias de lactação, produção de leite no pico e duração da lactação de vacas da raça holandesa. 


\section{REVISÃO DE LITERATURA}

\subsection{Mastite}

A mastite é uma reação inflamatória da glândula mamária às agressões microbiológicas, químicas, térmicas ou mecânicas. A inflamação caracteriza-se por aumento de volume, calor, vermelhidão, dor e/ou distúrbio funcional, resultando em diminuição da produção de leite e variação de sua composição (Park \& Jacobson, 1996).

Segundo Neave et al. (1969) $90 \%$ das mastites são causadas por bactérias, principalmente Sthaphilococcus aureus e bactérias do gênero Streptococcus. Além destes patógenos também podem ocorrer mastites causadas por fungos, leveduras, algas (Blood \& Radotitis, 1989) e vírus, porém as mastites causadas por este último patógeno são extremamente raras (Guidry, 1985).

O desenvolvimento da mastite pode ser satisfatoriamente explicado por três fases: Invasão, Infecção e Inflamação (Blood \& Radotitis, 1989).

A invasão é a fase em que os microrganismos passam do exterior para o interior da glândula através do canal do teto (Jain, 1979), são raros os relatos de casos de mastite causada por entrada de bactéria através de circulação (Guidry, 1985) o que faz com que o canal do teto seja considerado não só a primeira barreira da glândula, mas também a mais importante (Philpot \& Nickerson, 1991; Giraudo, 1996).

A infecção é a fase após o microrganismo ter alcançado o interior da glândula e inicia a sua adesão e crescimento no tecido mamário, sendo que 
esta pode ser freqüente ou ocasional dependendo da susceptibilidade do tecido mamário (Blood \& Radotitis, 1989).

Finalmente, a ação microbiana estimula a resposta do animal, sendo esta a fase da inflamação (Blood \& Radotitis, 1989). As características deste processo são rubor, turgor, calor e dor, com aumento da permeabilidade dos vasos sangüíneos e direcionamento de leucócitos para o tecido inflamado (D'Arce \& Flechtmann, 1980).

Segundo Blood \& Radotitis (1989) e Philpot \& Nickerson (1991) a mastite pode ser classificada em subclínica e clínica. A mastite clínica apresenta anormalidades na secreção láctea, anormalidade no tamanho, consistência e temperatura das glândulas mamárias e possivelmente reação sistêmica.

A mastite subclínica é aquela na qual existe a inflamação porém sem a apresentação de sinais visíveis da doença, sendo necessária a análise dos componentes do leite (como a contagem de células somáticas) e/ou a cultura do mesmo para sua detecção (Jain, 1979; Philpot, 1979).

\subsection{Contagem de Células Somáticas}

A Contagem de células somáticas (CCS) presentes na secreção lactea é um indicador geral da saúde da glândula mamária (Reneau, 1986).

Normalmente são células de defesa ( leucócitos) do organismo que migram do sangue para o interior da glândula mamária com o objetivo de combater agentes agressores, mas também podem ser células secretoras descamadas (Machado et al., 1999).

Uma glândula mamária saudável apresenta de 50.000 a 200.000 células por $\mathrm{ml}$, já acima de 283.000 cél./ ml a glândula é considerada infectada e nos casos clínicos a contagem de células somáticas chega a milhões de células por ml (Nickerson, 1985; Guidry, 1985; Reneau, 1986; Sordillo et al., 1997).

Não existe uma padronização internacional para a definição da infecção intramamária (IMI) e os métodos para definir a saúde da glândula mamária 
variam (Laevens et al., 1997)

Uma vez que a medida da CCS é fácil e barata quando comparada com testes bacteriológicos para mastite, ela tem sido usada para monitorar a saúde da glândula indicando animais infectados ou não. $O$ valor de corte utilizado para se classificar a glândula como sã ou mastítica é 283.000 células somáticas por $\mathrm{ml}$ de leite, sendo 80 \% eficiente nesta classificação (Reneau, 1986; Gadini et al., 1997b).

As defesas celulares intramamárias são realizadas por dois grupos de leucócitos, os linfócitos B e T que atuam na imunidade humoral e mediada por células, e os fagócitos (neutrófilos e macrófagos) que atuam pela ingestão e digestão dos patógenos mamários (Paape et al., 1991).

\subsubsection{Neutrófilos Polimorfonucleares}

Neutrófilos são células de defesa que possuem a função de capturar e destruir material estranho através da fagocitose. Sua formação se dá na medula óssea, migram para a corrente sangüínea e após 12 horas migram para os tecidos. Seu tempo de vida total é de poucos dias (Tizard, 1996).

Com um diâmetro de $12 \mu \mathrm{m}$, possuem um núcleo segmentado e um citoplasma finamente granulado, Estes grânulos são divididos em dois tipos principais, os grânulos primários que contêm mieloperoxidases, lisozima, proteases neutras e hidrolases ácidas e os grânulos secundários que possuem lisozima, colagenase e lactoferrina (figura 1) (Tizard, 1996). 


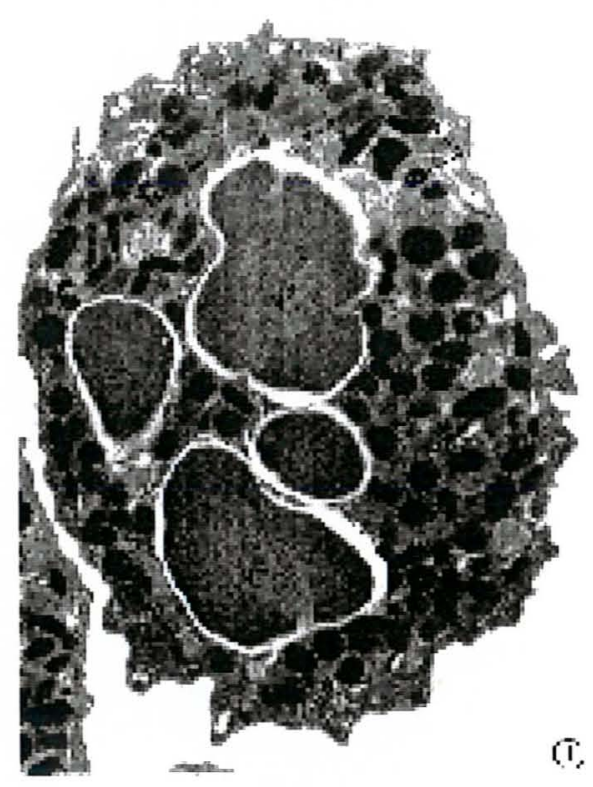

Figura 1. Neutrófilo sangüíneo bovino, que contêm núcleo lobulado e apresenta intensa granulação (Fonte: Paape et al., 1979).

No úbere inflamado os neutrófilos são as células mais numerosas, perfazendo um total de $90 \%$ das células somáticas. Eles se dirigem para a glândula por indução quimiotáxica provocada por peptídios liberados pelas bactérias, peptídio C5a gerado pela ativação do sistema complemento, fibrinopeptídio B derivado do fibrinogênio, leucotriene $B_{4}$ (Paape et al., 1979; Tizard, 1996;).

O primeiro passo para a migração dos neutrófilos é a sua aderência a parede dos vasos sangüíneos; eles flutuam livremente pela corrente sangüínea e ao passar por vasos em regiões de tecido injuriado encontram moléculas de aderência (P-seletinas) expostas pela parede endotelial. Estas moléculas se ligam a L-seletinas da membrana dos neutrófilos, mas esta ligação não é muito intensa e é rapidamente desfeita, assim o neutrófilo vai sendo freiado rolando pela superfície do endotélio. Neste momento se inicia a segunda fase da adesão, que é a ação do lipídio PAF que faz o neutrófilo parar completamente. Uma vez que ele está firmemente preso à parede do endotélio ele introduz seus pseudópodos entre as células e migra para os espaços intercelulares dos 
tecidos num processo conhecido como diapedese (Tizard, 1996).

Após as células somáticas atravessarem as paredes dos vasos, elas se acumulam em volta dos alvéolos, dutos e cisternas antes de entrar no leite, e na sua migração, estas células podem provocar danos ao tecido secretor, diminuindo a produção de leite (Nickerson, 1985; Philpot \& Nickerson, 1991; Sordillo et al., 1997).

No interior da glândula os neutrófilos promovem a fagocitose. Fagocitose é o processo de reconhecimento, ingestão, e digestão de partículas estranhas (bactérias, tecidos necróticos, tumores, etc) por células fagocíticas (Guidry, 1985).

Uma vez que o neutrófilo encontre uma partícula estranha ele deve aderir a essa partícula para promover a fagocitose completa, mas a adesão não é espontânea pois células em suspensão nos fluidos corporais possuem carga negativa (potencial zeta) se repelindo mutuamente; assim as bactérias devem sofrer o processo de opsonização, isto é o recobrimento com opsoninas (proteínas com cargas positivas que podem ser anticorpos ou o complemento C3b) (Tizard, 1996).

A ingestão ocorre pelo emissão de pseudópodos do neutrófilo que circundam a bactéria, e ao se fundirem formam o fagossomo. O fagossomo então se desprende da membrana e entra no citoplasma onde ocorrerá fusão com os grânulos formando o fagolisossomo (Pelczar, 1996).

Uma vez ingerida, a destruição da bactéria ocorrerá através de dois mecanismos distintos: a explosão respiratória e a digestão por enzimas lisozimais (Tizard, 1996).

Segundo Tizard (1996) a explosão respiratória é uma cadeia de reações que leva à destruição das bactérias. Após o seu início o consumo de oxigênio pelo neutrófilo aumenta em aproximadamente 100 vezes. A aderência do receptor $\mathrm{CD} 32$ da membrana celular com a bactéria ativa o processo através da ativação da enzima NADPH-oxidase: 


$$
\begin{aligned}
& \mathrm{NADPH}+2 \mathrm{O}_{2}-{ }^{\mathrm{NADPH}-\text { oxidase }} \longrightarrow \mathrm{NADP}^{+}+\mathrm{H}^{+}+2 \cdot \mathrm{O}_{2}^{-} \\
& 2 \cdot \mathrm{O}_{2}^{-}+2 \mathrm{H}^{+} \longrightarrow \mathrm{H}_{2} \mathrm{O}_{2}+\mathrm{O}_{2} \\
& \mathrm{H}_{2} \mathrm{O}_{2}+\mathrm{Cl}^{-}-\text {Mieloperoxidase } \longrightarrow \mathrm{H}_{2} \mathrm{O}+\mathrm{OCl}^{-}
\end{aligned}
$$

O OCl mata as bactérias por oxidar suas proteínas e aumentar a atividade das enzimas lisozimais. Além do $\mathrm{Cl}$-, também pode reagir o $\mathrm{Br}^{-}, \mathrm{I}^{-}$ou o $\mathrm{SCN}^{-}$.

O segundo mecanismo de destruição bacteriana envolve a ação das enzimas dos lisossomas que digerem a parede bacteriana e matam os microrganismos, as bactérias gram-positivas são rapidamente mortas mas as gram-negativas, devido ao fato de sua membrana externa da parede bacteriana ser mais resistente a digestão, podem sobreviver por mais tempo (Tizard, 1996).

Os neutrófilos têm sua eficiência fagocitária reduzida no leite Paape et al. (1979) atribui essa redução de eficiência a vários possiveis fatores como:

- menor reserva de glucogênio (38\% menos) nos neutrófilos presentes no leite;

- menor quantidade de opsonina no leite;

- ingestão de gordura e caseína no leite pelo neutrófilo que leva diminuição do suprimento de enzimas (figura 2);

- recobrimento da superfície do neutrófilo com caseína (Guidry, 1985);

- perda de pseudópodos via ingestão de gordura (Guidry, 1985).

Além disso os neutrófilos são removidos da glândula pela ordenha ou por fagocitose realizada pelos macrófagos, tendo assim um curto período de viabilidade, 1 a 2 horas) (Giraudo, 1996). 


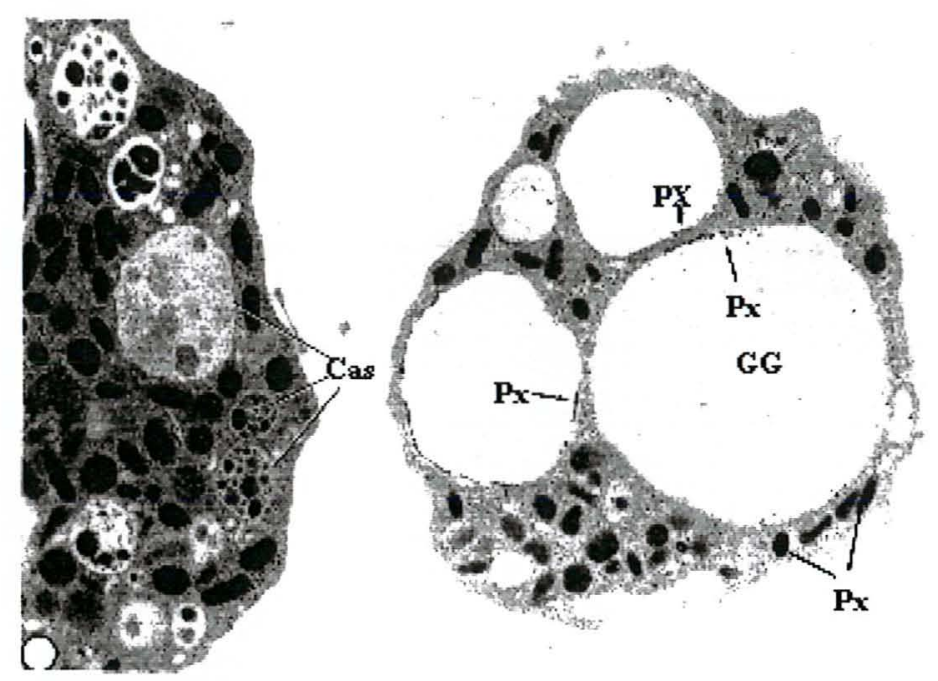

Figura 2. Neutrófilos com fagossomos contendo gordura e caseína (Adaptado de Paape et al. 1979). Legenda: $G G=$ glóbulo de gordura, Cas = grânulo de caseína, Px = peroxidases.

\subsubsection{Macrófagos}

Macrófagos são células de defesa que como os neutrófilos possuem a função fagocítica, alem disso também tem a função de secretar citocinas com importante papel na regulação da imunidade. A medula óssea libera no sangue macrófagos imaturos (monócitos) que após 3 dias migram para os tecidos onde se transformam em macrófagos maduros com seu nome variando em função do tecido em que está localizado. Seu tempo de vida total é relativamente longo, sendo renovados a uma taxa de $1 \%$ ao dia quando não estão ativados por inflamação ou dano tecidular (Tizard, 1996).

Com um diâmetro de $15 \mu \mathrm{m}$, possuem um abundante citoplasma com um núcleo central (figura 3), possui também um grande número de lisossomos e possui retículo endoplasmático e complexo de Golgi, indicando a habilidade de sintetizar e secretar proteínas (Tizard, 1996). 


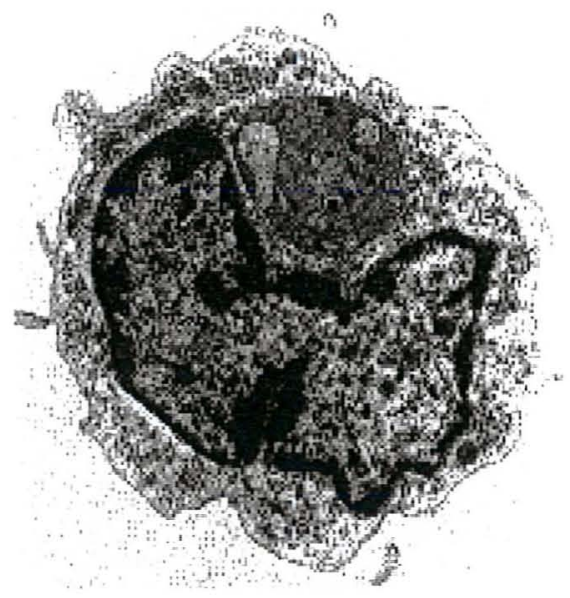

Figura 3. Macrófago com um grande fagossomo com conteúdo desconhecido (Fonte: Tizard, 1986).

A fagocitose realizada por macrófagos é semelhante a realizada por neutrófilos, mas eles são mais potentes que os PMN, sendo capazes de fagocitar, no sangue, até 100 bactérias enquanto que os PMN são capazes de fagocitar de 5 a 20 bactérias antes de se tornar inativos e morrer. Além disso os macrófagos também fagocitam células bovinas mortas ou agonizantes (Guytonn, 1992; Tizard, 1996).

O principal meio de destruição das bactérias ocorre pela produção de $\mathrm{NO}_{2}$, $\mathrm{NO}_{2}{ }^{-}, \mathrm{N}_{2} \mathrm{O}_{3}, \mathrm{ONOO}^{-}$e $\mathrm{NO}_{3}$ que são muito tóxicos (Tizard, 1996):

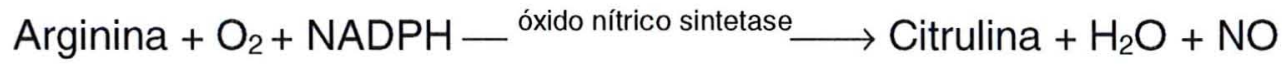

$$
\begin{aligned}
& 2 \mathrm{NO}+\mathrm{O}_{2} \longrightarrow 2 \mathrm{NO}_{2} \\
& 2 \mathrm{NO}_{2} \leftrightarrow \mathrm{N}_{2} \mathrm{O}_{4} \longrightarrow \mathrm{NO}_{2}{ }^{-}+\mathrm{NO}_{3}{ }^{-}
\end{aligned}
$$

Macrófagos podem sintetizar e secretar muitas proteínas. Algumas são secretadas continuamente como a lisozima e os complementos C2, C3, C4, e C5, outras são secretadas durante a fagocitose como as proteases, colagenases, elastases e ativadores do plasminogênio. Secretam também citocinas como as interleucinas (IL) 1, 2, 6 e 12 e o Fator $\alpha$ de necrose tumoral (Tizard, 1996). 
Interleucina 1 (IL-1) é um polipetídio de baixo peso molecular que possui efeito sobre o centro de temperatura do hipotálamo provocando a febre, possui também um efeito de estimular a medula óssea a aumentar a hematopoiese, estimular os linfócitos $B$ a produzir anticorpos, estimular os linfócitos $T$ a produzir IL-2 e interferon $\delta$, estimular a produção dos hormônios glucocorticóides e insulina, e finalmente ativar outros macrófagos. Existem duas formas ativas de IL-1: a IL-1 $\alpha$ e a IL-1 $\beta$, a forma $\beta$ é produzida em quantidade de 10 a 50 vezes maior que a $\alpha$, e é secretada pela célula, enquanto que a $\alpha$ se mantêm retida a menbrana celular (Kehrli, 1991; Verhoef, 1991; Tizard, 1996).

A Interleucina 2 (IL-2) é uma glicoproteína que estimula a proliferação de linfócitos $T$ e $B$, estimula a secreção de imunoglobulinas, estimula a produção de superóxidos em macrófagos ativados, aumenta a ação células NK ("natural killer"), também pode ter efeito na proliferação e atividade biosintética de células neurais como os oligodendrócitos e estimula a produção de ACTH. Apesar de também serem produzidas por macrófagos, seus principais produtores são os linfócitos (Warr \& Cohen, 1991; Daley et al., 1991; Erskine et al., 1998).

A Interleucina 6 (IL-6) atua em variadas células alvo incluindo linfócitos, fibroblastos e hepatócitos. No fígado atua no sentido de estimular a liberação de proteínas de fase aguda, e nos linfócitos atua estimulando a produção de anticorpos (Tizard, 1996).

A Interleucina 12 (IL-12) é um heterodímero composto por duas glicoproteínas. Esta citocina possui um papel comparável ao da IL-1 na estimulação na atividade dos linfócitos $T$ auxiliares no entanto enquanto a IL-1 estimula os Linfócitos Th 2. A IL-12 estimula os linfócitos Th 1 estimulando sua secreção de IL-2, interferon gama (INF - $\delta$ ) assim como receptores para IL-2, Além disso a IL-12 estimula a atividade das células matadoras e a secreção de imunoglobulinas nos linfócitos B (Tizard, 1996).

O Fator $\alpha$ de necrose tumoral (TNF- $\alpha$ ) é uma citocina que tem a habilidade de provocar a morte programada de células mesmo que esta não seja sua atividade principal. O TNF- $\alpha$ é mediador de muitas funções inflamatórias e 
imunes e regula o crescimento de muitos tipos de células, assim como também pode ativar os próprios macrófagos (Tizard, 1996).

Além da regulação do sistema imune através da produção de citocinas, os macrófagos também atuam na regulação através do processamento e exposição dos antígenos ao sistema imune. Após sua ingestão os antígenos bacterianos são processados (quebrados em fragmentos) no interior dos macrófagos e são expostos na membrana ligados a moléculas específicas de apresentação de antígeno a linfócitos $T$ auxiliares, esta molécula é o complexo de histocompatibilidade principal (MHC) classe II. Estes receptores glicoproteicos, necessários para que os linfócitos reconheçam os antígenos estranhos, recebem o nome de coletivamente de antígenos leucócitos bovino (BoLA) (Darnell et al., 1990; Giraudo, 1996; Tizard, 1996; Sordillo et al., 1997).

O macrófagos predominam na secreção mamária não infectada, sendo responsáveis portanto pelo inicio do ataque aos patógenos, mas na glândula infeccionada ocorre predomínio dos neutrófilos chegando se a mais que $90 \%$ das células somáticas (Tabela 1) (Paape, 1979; Rebhun, 1995; Giraudo, 1996).

Tabela 1. Porcentagem dos diferentes tipos de células de defesa no interior da glândula mamária não infectada nos diferentes estados fisiológicos.

\begin{tabular}{cccc}
\hline Estado da glândula & Macrófagos & Neutrófilos & Linfócitos \\
\hline Lactação & 60 & 12 & 28 \\
Recém seca & 40 & 40 & 20 \\
(1-20 dias) & & & \\
Seca (involuída) & 44 & 17 & 39 \\
\hline
\end{tabular}

Adaptado de Giraudo, 1996.

Assim como os neutrófilos, os macrófagos também possuem uma atividade fagocítica menos efetiva no leite (Sordillo et al., 1997). 


\subsubsection{Linfócitos}

Linfócitos são células responsáveis pelo reconhecimento de antígenos estranhos e por montar a resposta imunológica. Assim como existe uma variedade de respostas (formação de memória imunológica, produção de anticorpos, resposta mediada por células) existe também uma variedade de populações de linfócitos (Clem et al., 1991; Tizard, 1996).

A mais fundamental classificação destas células envolve sua separação em células $T, B$ e células NK. Os linfócitos $B$ são linfócitos antigênicoespecíficos que são identificados pela presença de imunoglobulinas na sua superfície e por sua habilidade de diferenciação de células secretoras de anticorpos em resposta a estímulo próprio. As células $T$ também são linfócitos antigênico-específicos, mas não exibem imunoglobulinas de superfície e se diferenciam em subpopulações citotóxicas, supressoras e auxiliares. As células NK são linfócitos não imunológicos, que possuem habilidade citotóxica na ausência do $\mathrm{MHC}$, entretanto possuem receptores $\mathrm{Fc}$ (receptores de superfície celular que se ligam a região $\mathrm{Fc}$ dos anticorpos) que permitem sua ação na citotoxidade mediada por células dependente de anticorpos. Esta célula tem mostrado habilidade de matar bactérias gram-positivas e gram-negativas por um mecanismo extracelular (Clem et al., 1991; Sordillo et al., 1997).

A medula óssea produz precursores de linfócitos que se diferenciam em pré-B e pré-T. A linhagem pré-B amadurece nas placas de Peyer (agregados de nódulos linfáticos grandes e visíveis encontrados na submucosa do jejuno, íleo e ceco variando em número de 18 a 40 no bovino adulto, figura 4) ou na própria medula óssea, a linhagem pré-T amadurece no Timo. Da linhagem pré-T não diferenciada surgem as células NK (Ferri et al., 1979; Habel, 1986; Venzke, 1986; Tizard, 1996).

Quanto a forma e tamanho, os linfócitos são células redondas e pequenas com diâmetro variando de 7 a $15 \mu \mathrm{m}$. Possuem um grande e redondo núcleo e um citoplasma estreito contendo algumas mitocôndrias, ribossomos, e um 
pequeno complexo de Golgi (figura 5), com exceção das células NK que são grandes e granulares (Tizard, 1996; Sordillo et al., 1997).
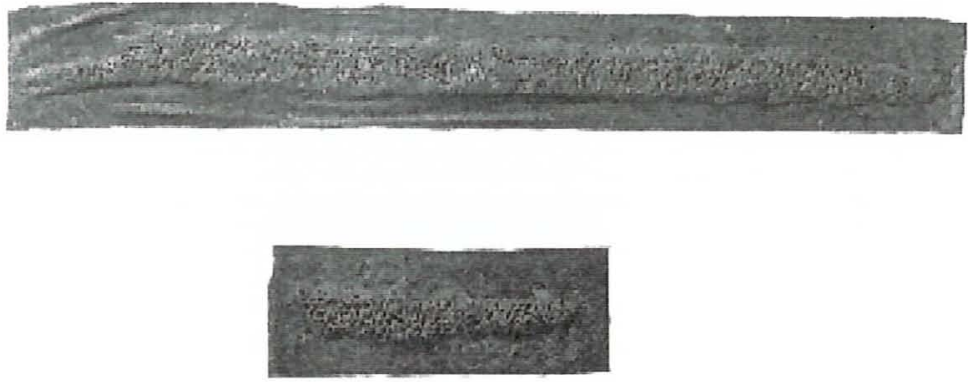

Figura 4. Pedaços da mucosa intestinal mostrando as Placas de Peyer (Fonte: Habel, 1986).

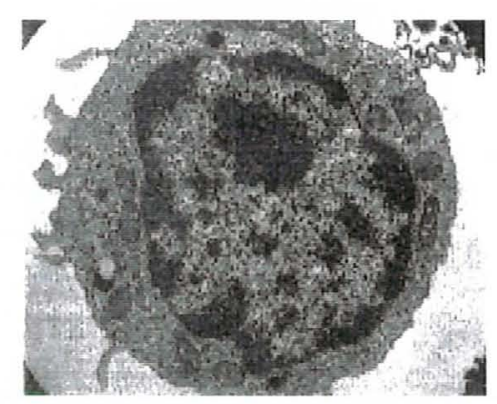

Figura 5. Linfócito de coelho, notar o grande núcleo e o estreito citoplasma (Fonte: Ferri et al., 1979).

Após o linfócito específico ter sido ativado pelo seu antígeno, ele passa a reproduzir-se intensamente, formando quantidades enormes de linfócitos de mesmo tipo que vão atuar no combate ao antígeno (Guytonn, 1992).

Os linfócitos B são responsáveis pela produção de anticorpos (receptores celulares solúveis das células $B$ ), além disso também podem agir como células processadoras de antígenos para apresenta-los aos linfócitos $T$ auxiliares (via MHC classe II). Alguns linfócitos $B$ ativados pelo antígeno se transformam em células de memória que se ativadas por uma segunda dose de antígeno 
produzem uma resposta imunológica mais rápida e intensa com maior produção de anticorpos e predominância de IgG (enquanto que no primeiro estímulo ocorre produção predominante de lgM) (Tizard, 1996; Sordillo et al., 1997).

Os linfócitos $T$ podem ser divididos em células $T \alpha \beta$ que inclui CD4+ (linfócitos $T$ auxiliares) e CD8+ ( linfócitos $T$ citotóxicos ou supressores) e células $T \gamma \delta$. Dependendo do estágio de lactação, suas proporções podem variar (Sordillo et al., 1997).

CD4 e CD8 são peptídeos presentes na membrana celular que determinam a qual classe de moléculas MHC o linfócito se ligará; sua importância está na transmissão do sinal uma vez que a estimulação do linfócito é ampliada em 100 vezes quando o CD 4 ou 8 está associado ao receptor celular. Os CD4 são encontrados em células T auxiliares e CD8 em células citotóxicas ou supressoras. No sangue a relação CD4/CD8 é $>1$, no entanto nos tecidos e secreção mamária saudável é < 1 como pode ser visto na tabela 2 (Park et al., 1992; Tizard, 1996; Sordillo et al., 1997).

Tabela 2. Relação média entre os linfócitos T CD4 e CD8 no sangue e secreção mamária durante a lactação.

\begin{tabular}{cc} 
Local & Relação CD4/CD8 \\
Sangue & 1,52 \\
Secreção Mamária & 0,82 \\
\hline
\end{tabular}

Adaptado de Park et al. (1992).

O linfócito $T$ auxiliar produz citocinas em resposta ao reconhecimento do complexo MHC-antígeno presente nos linfócitos B ou macrófagos. Através desta habilidade de produzir citocinas estes linfócitos desempenham um importante papel na ativação das células envolvidas na atividade imunológica (Sordillo et al., 1997).

Existem duas sub populações dos linfócitos $T$ auxiliares que se diferenciam pelas citocinas que liberam e pela resposta ótima a célula 
apresentadora de antígeno. O Th1 responde de maneira ótima ao antígeno apresentado pelos linfócitos $B$, enquanto que 0 Th2 apresenta resposta otimizada ao antígeno apresentado pelos macrófagos, assim a proporção relativa entre as células apresentadoras de antígenos determinará a natureza da resposta dos linfócitos $T$ auxiliares. As citocinas produzidas pelo Th1 são principalmente IL-2 (ativa células T, B, NK e macrófagos) e interferon- $\gamma$ (inibe Th2, estimula Th1, e ativa células NK e macrófagos). As principais citocinas produzidas por linfócitos Th2 são IL-4 (estimula crescimento e diferenciação de células $B$ ), IL-5 (estimula crescimento e ativação de eosinófilos e crescimento de células $B$ ), IL-10 (inibe função das células Th1 e macrófagos) e IL-13 (estimula crescimento dos linfócitos $B$ e suprime a função dos macrófagos) (Tizard, 1996).

Os linfócitos $T$ citotóxicos reconhecem e eliminam células alteradas através da apresentação do antígeno em conjugação com as moléculas MHC classe 1, desse modo removem células secretoras velhas e danificadas que poderiam aumentar a susceptibilidade da glândula mamária a infecções. Os linfócitos $T$ supressores modulam a resposta imunológica, impedindo uma reação imune muito intensa capaz de lesar gravemente o organismo (Guyton, 1992; Sordillo et al., 1997).

As células $T$ com receptores $\gamma \delta$ dos ruminantes podem se ligar a uma variedade de antígenos e serem citotóxicos tendo assim uma importancia funcional. Em contraste com as células $\gamma \delta$ de humanos e roedores que compõem de 1 a $3 \%$ dos linfócitos no sangue periférico, em ruminantes podem chegar a $60 \%$ (Tizard, 1996).

Na secreção mamária, linfócitos perfazem 20 a $40 \%$ do total de células e na população de linfócitos as células T perfazem 50 a $60 \%$, células B perfazem 10 a $20 \%$, e os linfócitos remanescentes são células sem função (Daniel et al,. 1991). 


\subsubsection{Fatores de variação}

\subsubsection{Sanidade da glândula mamária}

O fator mais importante afetando a CCS é o "status" da infecção da glândula mamária, embora existam outros fatores menos importantes (Reneau, 1986; Harmon, 1994; Harmon, 1998).

A atividade dos microrganismos no interior da glândula mamária libera substâncias que estimulam a migração de leucócitos a fim de combater os agentes agressores (Machado et al., 1998 e 1999), aumentando assim a CCS.

Os agentes da mastite apresentam variação na resposta causada na glândula mamária. O patógenos maiores da mastite provocam médias de CCS mais elevadas que os patógenos menores (tabela 3) (Reneau, 1986; Blood \& Radotits, 1989).

Esta variação é devida as características do agente etiológico (Amaral, 1999).

Tabela 3. Valores de CCS transformados e os patógenos da mastite.

\begin{tabular}{cccc}
\hline Grupo* & Patógeno & $\begin{array}{c}\text { Schepers et al. } \\
(1997)^{\star \star}\end{array}$ & $\begin{array}{c}\text { Wilson et al. } \\
(1997)^{\star \star \star}\end{array}$ \\
\hline Maiores & Staphilococcus aureus & 5,98 & 5,1 \\
& Streptococcus agalactiae & - & 5,6 \\
& Streptococcus spp. & - & 5,1 \\
& Streptococcus dysgalactiae & 6,34 & - \\
\multirow{4}{*}{ Menores } & Streptococcus uberis & 6,72 & - \\
& Corynebacterium bovis & 3,96 & 3,9 \\
& Staphilococcus coag. neg. & 4,22 & - \\
- & Cultura negativa & 2,64 & 3,0 \\
\hline
\end{tabular}

${ }^{*}$ Classificação segundo Harmon (1998),

* CCS transformada para função In, 
*** CCS transformada para função EL

No entanto não é possível identificar o patógeno somente através da CCS (Harmon, 1994).

\subsubsection{Outros fatores}

Há poucas evidências de que qualquer outro fator, com exceção da variação diurna normal, tenha uma influência significativa na CCS na ausência de infecção intramamária (Harmon, 1998).

\section{VARIAÇÃO DIURNA}

A ordenha da tarde apresenta maiores CCS em relação a ordenha da manhã (Hargrove, 1994; Vasconcelos et al., 1997).

Esta diferença pode ser explicada pelo intervalo de tempo desigual entre as ordenhas que leva a diferentes produções de leite (Fuente et al., 1997) e consequente efeito de diluição das células somáticas (Philpot \& Nickerson, 1991).

Logo após a ordenha o CCS é máxima permanecendo elevada por 4 horas e depois declina gradualmente atingindo a contagem mínima imediatamente antes da próxima ordenha (Harmon, 1998).

\section{NÚMERO DE LACTAÇÕES}

Animais ou quartos mamários não infectados não apresentam efeito significativo do número de lactações sobre a CCS, assim o número de lactações pode ser desconsiderado para predizer a ocorrência de infecção intramamária (Sheldrake et al., 1983; Laevens et al., 1997).

Os aumentos de CCS relacionados ao aumento da ordem de lactação do animal são de origem bacteriana pois a incidência de mastite aumenta significativamente com o aumento do número de lactações (Reneau, 1986; Prynce et al., 1999). 


\section{ESTÁGIO DA LACTAÇÃO}

O estágio da lactação não afeta significativamente a CCS quando não existe infecção, assim este fator pode ser desconsiderado quando do diagnóstico de infecção intramamária através da CCS (Sheldrake et al., 1983; Laevens et al., 1997).

O aumento da CCS atribuído a avanço da lactação é devido a infecção (Sheldrake et al., 1983).

\section{ESTRESSE}

Estresses de vários tipos tem sido associados ao aumento da CCS, mas experimentos com aplicação de ACTH ou corticoesteróides ou com o uso de ambiente controlado em animais não infectados não mostram efeito sobre a CCS (Paape et al., 1973; Harmon, 1994).

Condições estressantes podem agravar o processo inflamatório em vacas infectadas, enquanto tem pouco efeito na CCS de vacas não infectadas (Harmon, 1998).

\section{ESTAÇÃO DO ANO}

A CCS é geralmente menor durante o inverno e maior durante o verão, mas este aumento é resultado de melhores condições ambientais para o crescimento bacteriano levando a maior exposição da ponta dos tetos aos patógenos, resultando em maior número de novas infecções e de casos clínicos (Reneau, 1986).

\subsubsection{Escore linear}

Por não ter distribuição normal, a CCS deve ser transformada para uma escala logarítmica e ser convertida em escore de células somáticas. A transformação fornece uma distribuição normal com homogeneidade de variância (Gadini et al. 1997a).

Para melhorar o entendimento e interpretação da CCS, O DHI (associação para o desenvolvimento dos rebanhos leiteiros norte americanos) 
propôs a padronização da transformação da CCS pela seguinte função (Dabdoub \& Shook, 1984; Kirk, 1984):

$$
E L=\left[\log _{2}(C C S / 100.000)\right]+3
$$

A maior vantagem de se utilizar o escore linear do $\mathrm{DHI}$ é a sua relação linear com a produção de leite o que facilita a interpretação dos dados (Raubertas \& Shook, 1982; Kirk, 1984;Reneau, 1986).

\subsection{Perdas de produção}

\subsubsection{Efeito sobre a produção}

Vários autores encontraram associação entre o aumento da CCS e diminuição da produção de leite (Kennedy et al., 1982; Miller et al., 1993; Gadini et al., 1997b).

Mesmo em baixos niveis de CCS ocorre redução de produção de leite associada a aumento da CCS, (Hornet et al., 1999). As perdas já são evidentes mesmo a uma CCS entre 100 e 200 mil cél./ml (Raubertas \& Shook, 1982).

Dados de Wisconsin e Virginia indicam que para cada aumento de uma unidade de escore linear ocorre diminuição de $181 \mathrm{Kg}$ de leite por lactação (Reneau, 1986).

Trabalhando com rebanhos, Fetrow et al. (1988) encontraram queda de $190 \mathrm{Kg}$ de leite na média do rebanho quando a média do escore linear do rebanho aumentava em uma unidade.

Dabdoub \& Shook (1984) encontraram perdas de $127 \mathrm{Kg}$ na primeira lactação, e 146 a $213 \mathrm{Kg}$ da segunda a quarta lactação. Estes autores também observaram aumento das perdas associadas ao aumento da ordem da lactação.

Para um dado nivel de CCS a redução na produção de leite aumenta com 
- número de parições ou com o estágio da lactação na qual a CCS foi observada (Hornet et al., 1999).

O aumento da redução da produção de leite pode ser explicada por piora na saúde do úbere em multíparas e/ou no final da lactação devido a um aumento na exposição a uma possível infecção e dano permanente a glândula por infecções prévias (Bartlett et al., 1990).

Além disso, vacas mais velhas também tendem a ter infecções mais longas e que causam danos mais extensos nos tecidos (Reneau, 1986).

Além da produção de leite, a mastite afeta outras características produtivas como a produção de gordura e a duração da lactação levando a sua redução (Kennedy et al., 1982; Machado et al., 1993; Gadini et al., 1997b; Norman et al., 1999).

\subsubsection{Estimativa da perda de produção}

Os efeitos da mastite na performance das vacas leiteiras não são facilmente quantificados, pois existe grande variabilidade na resposta de produção em relação a mastite. Estas variações são devidas a diferenças nas populações estudadas, aos indicadores da mastite e ao método estatístico utilizado (Lescourret \& Coulon, 1994; Hornet et al. 1999).

Diferentes métodos tem sido utilizados para o estudo dos efeitos da mastite sobre a produção, um deles é a modelagem da alteração da produção em 305 dias em lactação associada ao aumento da média da CCS (ou respectivo EL) durante a lactação (Raubertas \& Shook, 1982; Hornet et al., 1999).

Este método é bastante adequado pois segundo Raubertas \& Shook (1982) a utilização da média de log CCS sozinha é adequado para estudo do efeito depressivo de elevada CCS na produção de leite e segundo Reneau (1986) a média do escore linear durante a lactação produz estimativas confiáveis enquanto que a estimativa da perda de produção ou do "status" da 
infecção baseada em uma simples CCS é fraca.

A média do log CCS da lactação anterior pode ser desconsiderada no estudo da lactação seguinte pois não possui efeito significativo na produção da mesma (Raubertas \& Shook, 1982)

Segundo Kirk (1984) o cálculo das perdas de produção associados a CCS pode sensibilizar os produtores e despertá-los para o problema da mastite subclínica. Segundo este autor o principal problema dos programas de controle de mastite é desviar a atenção da mastite clínica para a subclínica. 


\section{MATERIAL E MÉTODOS}

Foram levantadas, no banco de dados do Laboratório de Fisiologia da Lactação da ESALQ - USP, informações referentes a 147 lactações encerradas de bovinos da raça holandesa, de um rebanho confinado do Estado de São Paulo.

O rebanho possui em média 398 vacas em lactação, da raça holandesa preto e branco. A média de produção anual é de $27,8 \mathrm{Kg} / \mathrm{vaca} / \mathrm{dia}$. Os animais são manejados em sistema de confinamento livre, e são ordenhados 3 vezes ao dia em uma única sala de ordenha do tipo espinha de peixe $12 \times 12$.

As taxas de mastite subclínica ( $E L>4,5$ ), mastite clínica, de novas infecções e taxa de mastite crônica são respectivamente 24,$9 ; 1,6 ; 13,5$ e 63,2 $\%$.

No rebanho predominam mastites causadas por patógenos menores (Corynebacterium bovis e Staphylococci coagulase negativa) (apèndice).

Das lactações, 83 eram de animais primíparos e 64 de animais multíparos. Como esta característica possui efeito reconhecido sobre a produção de leite (Kaabi et al., 1999), sobre a incidência de mastite (Pryce et al., 1999) e sobre o comportamento da CCS (Schultz et al., 1990) optou-se em estudar separadamente o efeito da CCS sobre os parâmetros produtivos de animais primíparos e multíparos.

As informações levantadas foram a produção de leite e gordura a 305 dias de lactação, a produção no pico de produção, a duração da lactação e as médias de escore linear na lactação e no seu inicio.

Escore linear é a transformação da CCS pela seguinte função $E L=\left[\log _{2}\right.$ (CCS/100.000)] + 3 (Dabdoub \& Shook, 1984). 
As análises estatísticas foram realizadas no pacote estatístico SAS (SAS, 1990), utilizando-se o procedimento de modelo lineares generalizados.

Os modelos estatísticos utilizados foram:

(1) $Y_{i}=m+E_{i}+e_{i}$;

Onde:

$Y_{i}=$ observação referente a produção de leite ou gordura, em $\mathrm{Kg}$, aos 305dias de lactação ou a duração da lactação, em dias, referente ao escore linear $\mathrm{i}$;

$\mathrm{m}=$ média geral;

$E_{i}=$ efeito do escore linear médio da lactação $i$, sendo $i=1, \ldots, 10$;

$e_{i}=$ erro aleatório associado a observação $Y_{\mathrm{i}}$.

(2) $Y_{i}=m+I_{i}+e_{i}$

Onde:

$Y_{i}=$ observação referente a produção de leite, em Kg, no pico de produção referente ao escore linear médio no início da lactação i;

$\mathrm{m}=$ média geral;

$\mathrm{I}_{\mathrm{i}}=$ efeito do escore linear médio do início dalactação $i$, sendo $i=1, \ldots, 10$;

$e_{i}=$ erro alaetório associado a observação $Y_{i}$. 


\section{RESULTADOS E DISCUSSÃO}

\subsection{Análise do rebanho}

A tabela 4 apresenta as médias e os índices de dispersão dos dados originais do rebanho.

Tabela 4. Médias e índices de dispersão dos dados originais de produção de leite e gordura em 305 dias de lactação, duração da lactação, produção de leite no pico, escore linear médio durante a lactação e média do escore linear durante o início da lactação de primíparas e multíparas.

\begin{tabular}{cccccccc}
\hline & Nobs. & Variável & Média & DevPad & CV (\%) & Mín & Máx \\
\hline Primíparas & 83 & PL305 & 8478 & 995,49 & 11,74 & 6124 & 10412 \\
& & PG305 & 308,2 & 52,24 & 16,95 & 189 & 508 \\
& DL & 378,5 & 66,98 & 17,70 & 305 & 532 \\
& & PICO & 33,4 & 4,73 & 14,17 & 20,6 & 43,8 \\
& DP & 61,4 & 9,54 & 15,52 & 40 & 75 \\
& & EL & 2,15 & 1,30 & 60,28 & 0,1 & 7,0 \\
& & MEDINI & 2,39 & 1,61 & 67,2 & 0,1 & 7,2 \\
& & PL305 & 10051 & 1250 & 12,44 & 7448 & 12611 \\
& & PG305 & 387,2 & 63,9 & 16,50 & 237,0 & 505,0 \\
& DL & 399,4 & 65,1 & 16,29 & 306,0 & 560,0 \\
& PICO & 44,4 & 5,3 & 11,87 & 33,0 & 56,4 \\
& DP & 55,3 & 8,7 & 15,73 & 45,0 & 75,0 \\
& & EL & 3,4 & 1,4 & 40,81 & 1,0 & 7,5 \\
& & MEDINI & 3,2 & 2,1 & 66,13 & 0,1 & 8,6 \\
\hline
\end{tabular}

Nobs = número de observações, 
DevPad = desvio padrão,

$\mathrm{CV}=$ coeficiente de variação,

Mín = mínimo,

Máx = máximo,

$\mathrm{PL} 305$ = produção de leite em 305 dias de lactação, em Kg,

PG305 = produção de gordura em 305 dias de lactação, em Kg,

$\mathrm{DL}=$ duração da lactação, em dias,

$\mathrm{PICO}=$ produção de leite no pico de lactação, em Kg,

DP = data de ocorrência do pico, em dias de lactação,

$E L=$ escore linear médio da lactação,

MEDINI = escore linear médio no inicio da lactação.

Os dados mostram que este rebanho apresenta alta produtividade, sendo superior as médias encontradas em rebanhos holandeses por Richter et al. (1995) e Pimpão et al. (1997) no Paraná, respectivamente, 6300 e $6400 \mathrm{Kg}$, e por Reis \& Silva (1987) e Barbosa (1990) em rebanhos de Minas Gerais (4500 $\mathrm{Kg})$ e Pernambuco $(4600 \mathrm{Kg})$.

A produção média de gordura também foi superior a dos trabalhos citados acima.

Este alto nível de produção é provavelmente devido as condições nutricionais e sanitárias deste rebanho. Colaborando com esta hipótese, o escore linear médio da lactação encontrado é de apenas 2,15 e 3,2 evidenciando uma boa condição de sanidade da glândula mamária.

A variabilidade dos dados se mostrou bastante adequada, os coeficientes de variação encontrados são inferiores aos CV das respostas animais em geral (20 a $30 \%$ ) (Sampaio, 1998). Este fato mostra o alto controle da atividade produtiva existente na propriedade.

No entanto o escore linear médio da lactação inteira e de seu inicio se mostraram altamente instáveis (CV 40 a $67 \%$ ). Esta alta instabilidade decorre de que com o bom manejo sanitário do rebanho poucos animais são afetados 
pela mastite de modo a apresentar média da lactação inteira de escore linear alto, predominando assim, baixos valores de EL nos dados .

\subsection{Primíparas}

A análise de regressão não mostrou efeito significativo do escore linear médio da lactação sobre a produção de leite e gordura em 305 dias em lactação, nem sobre a duração da lactação, e nem efeito escore linear médio do inicio da lactação sobre a produção de leite no pico e a data do mesmo (tabela $5)$.

Tabela 5. Resumo da análise de regressão do efeito do escore linear médio da lactação sobre a produção de leite e gordura em 305 dias em lactação, sobre a duração da lactação, e efeito escore linear médio do inicio da lactação sobre a produção de leite no pico e a data do mesmo em primíparas.

\begin{tabular}{lcccc}
\hline & $\begin{array}{c}\text { gl } \\
\text { modelo }\end{array}$ & $\begin{array}{c}\text { gl } \\
\text { resíduo }\end{array}$ & $\begin{array}{c}\text { gl } \\
\text { total }\end{array}$ & $\begin{array}{c}\text { nis } \\
(\%)\end{array}$ \\
\hline PL305 & 1 & 81 & 82 & $\mathrm{~ns}$ \\
PG305* & 1 & 81 & 82 & $\mathrm{~ns}$ \\
DL** & 1 & 81 & 82 & $\mathrm{~ns}$ \\
PICO & 1 & 81 & 82 & $\mathrm{~ns}$ \\
DP & 1 & 81 & 82 & $\mathrm{~ns}$ \\
\hline gl = graus de liberdade, & & & \\
nis = nível de significância do modelo, & \\
PL305 = produção de leite em 305 dias de lactação, \\
PG305 = produção de gordura em 305 dias de lactação, \\
PICO = produção de leite no pico de lactação, \\
DL = duração da lactação, \\
DP = data do pico de lactação. \\
* Transformado por indicação da análise de máxima verossimelhança para
\end{tabular}


$\log _{10}$

* Transformado por indicação da análise de máxima verossimelhança para $1 / \mathrm{DL}$.

A ausência de significância do efeito do EL sobre os parâmetros estudados contraria a literatura (Raubertas \& Shook, 1982; Miller et al., 1993; Graafa \& Dwingerb, 1996), mas pode ser explicado pela quase inexistência de animais primíparos com EL médio da lactação acima de 4,5 (figura 6 a 9).

EL

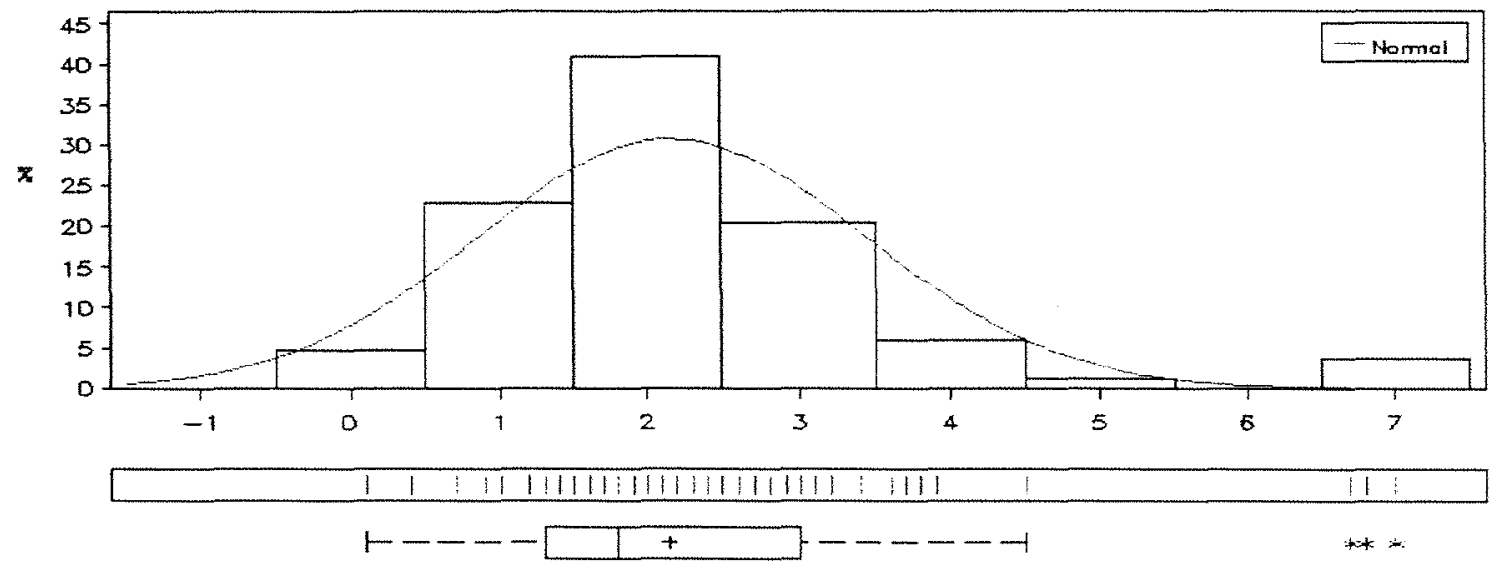

Figura 6. Distribuição dos dados de EL das primíparas.

A figura 6 mostra que praticamente todos os animais primíparos do rebanho estudado apresentam EL médio da lactação abaixo de 4,5. Desse modo a análise de regressão não indicou efeito significativo do EL sobre a produção de leite e gordura aos 305 dias de lactação (figuras 7 e 8), nem sobre a duração da lactação (Figura 9). 


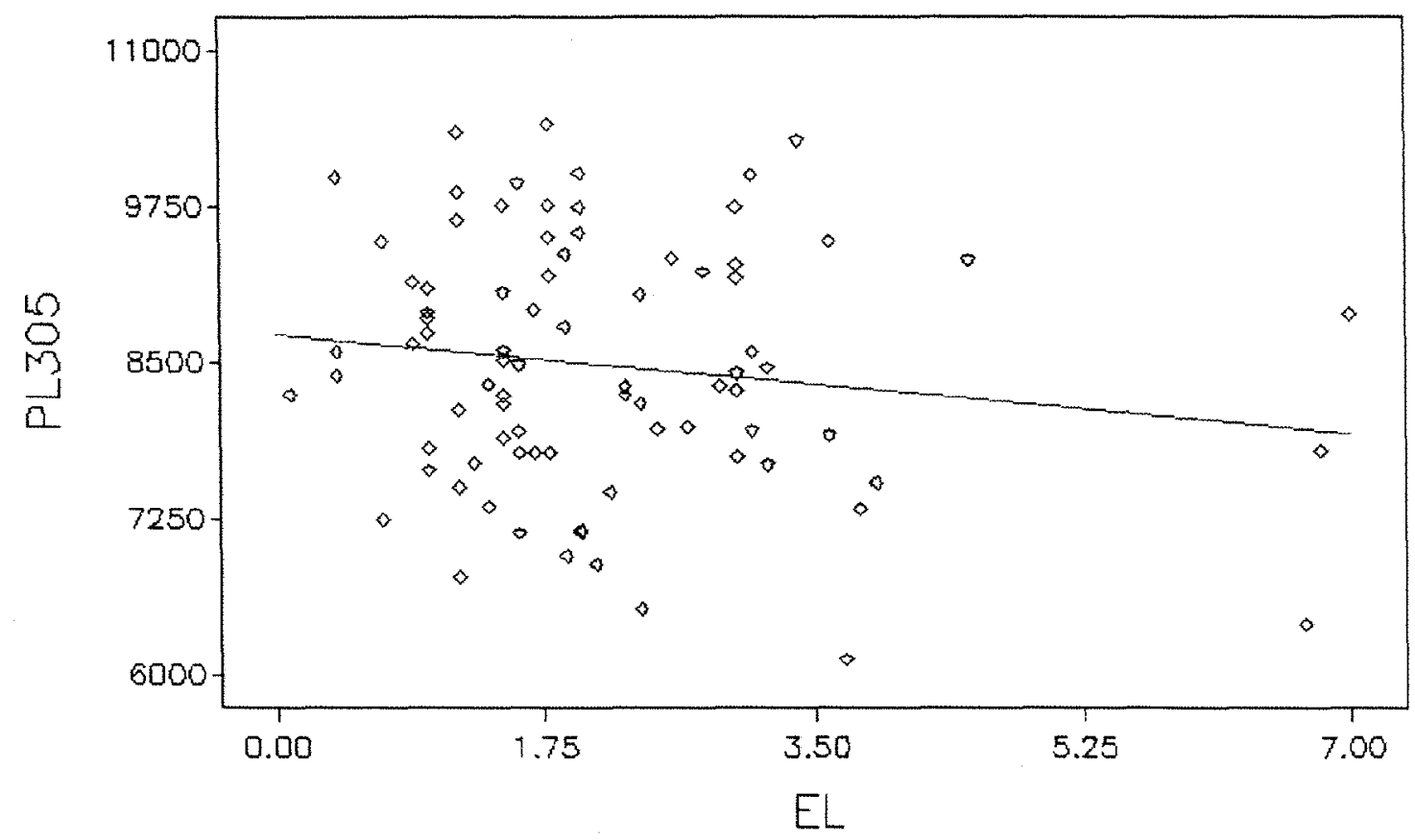

Figura 7. Produção de leite $(\mathrm{Kg})$ em 305 dias em lactação em função do escore linear médio da lactação (EL) dos animais primíparos.

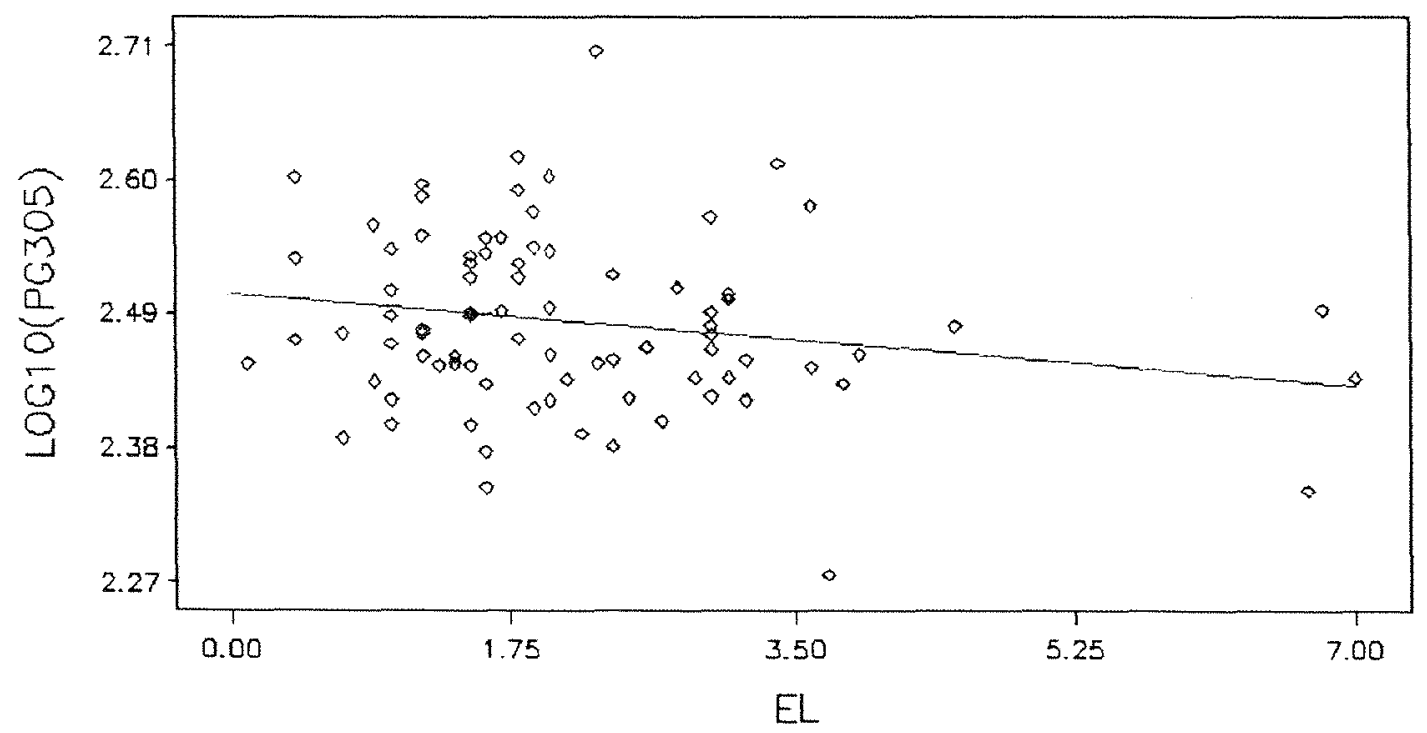

Figura 8. Efeito do EL médio da lactação sobre a PG305 (Kg) transformada para $\log _{10}$ dos animais primíparos. 


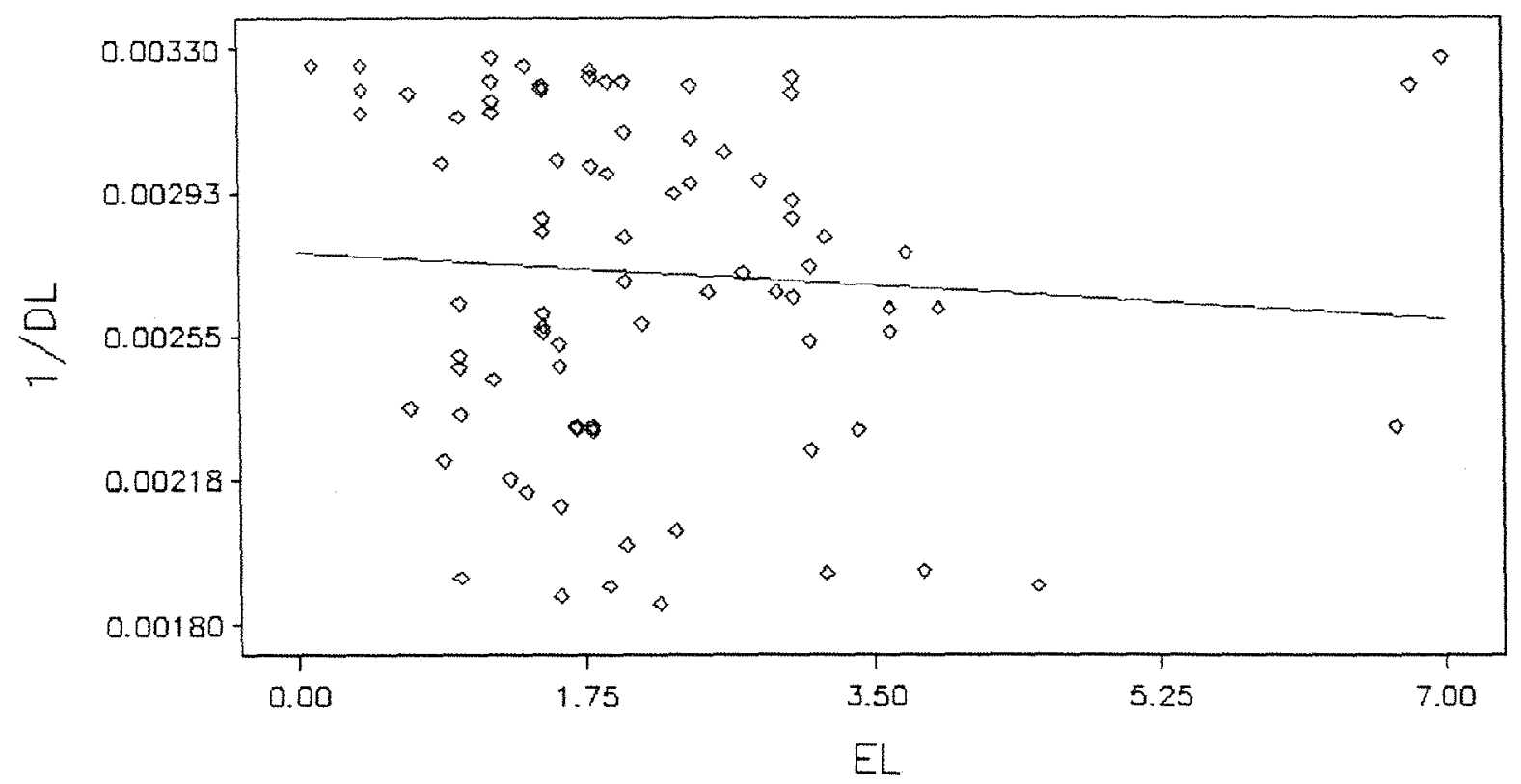

Figura 9. Efeito do EL médio da lactação sobre o inverso da duração da lactação dos animais primíparos.

Pelos dados apresentados pode se concluir que médias de EL da lactação inteira abaixo de 3,5 não afetam as características produtivas de primíparas nas condições estudadas.

Tomando-se a literatura como base, pode-se supor que se o rebanho estudado tivesse um maior número de animais primíparos com EL maior teria sido possível detectar efeito deletério significativo do EL sobre a produção dos mesmos.

A distribuição dos dados de média de escore linear no início da lactação (MEDINI) também se comportou como a distribuição dos dados de escore linear médio da lactação inteira ( $E L)$ com pequeno número de animais com valores mais altos (figura 10). 


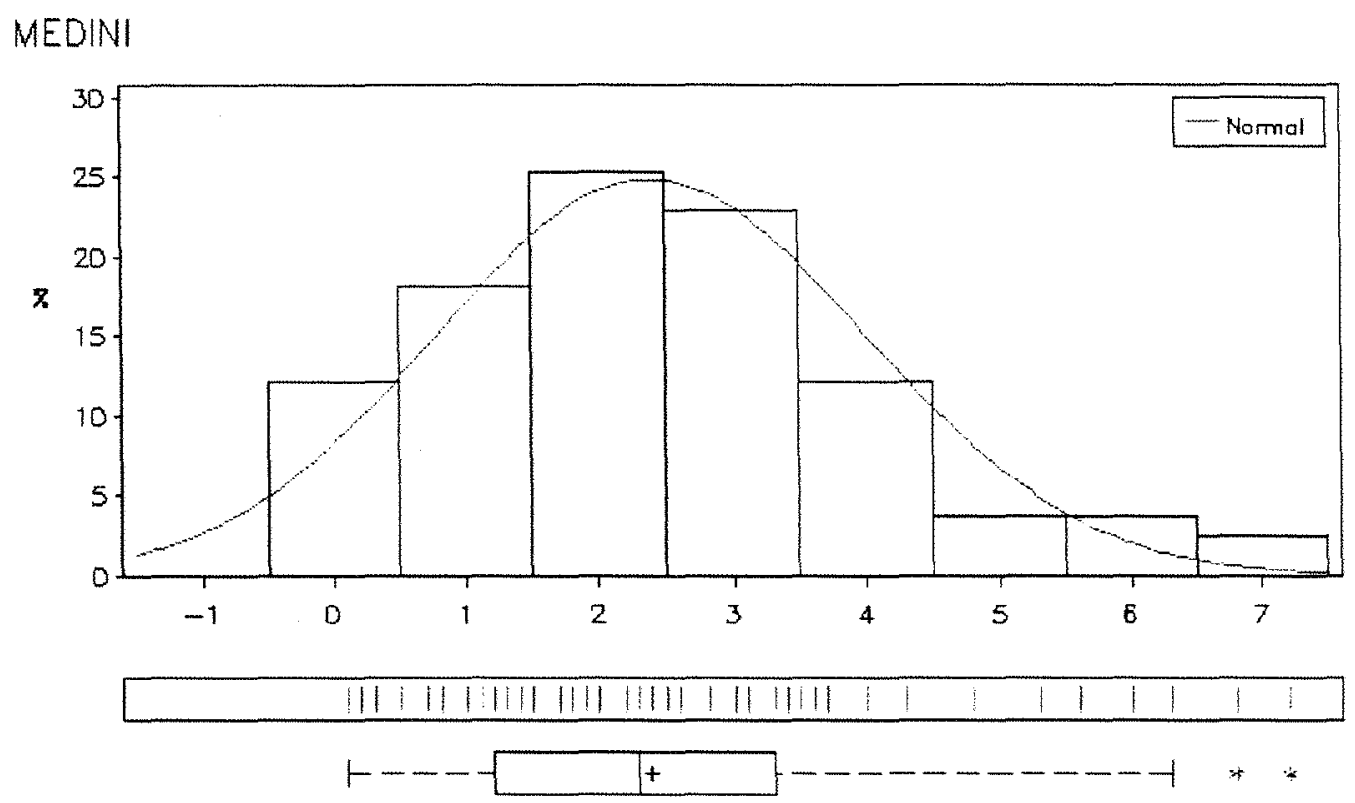

Figura 10. Distribuição dos dados de MEDINI das primíparas.

Esta baixa freqüência de animais com média de escore linear no início da lactação (MEDINI) acima de 4,5 levou a análise de regressão a não detectar efeito da mesma sobre a produção de leite no pico da lactação (PICO) nem sobre a data de ocorrência do mesmo (DP) (figura 11 e 12). 


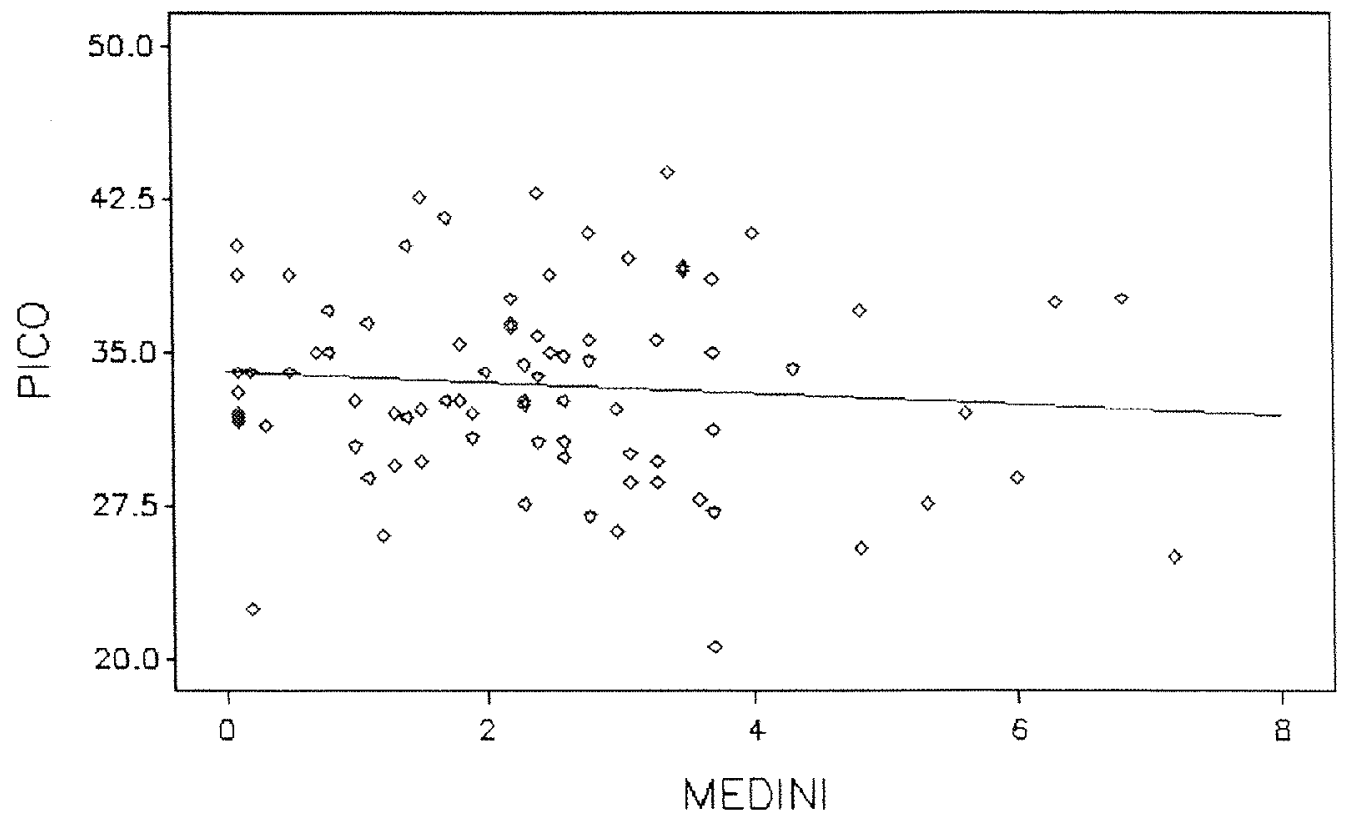

Figura 11. Efeito do EL médio do início da lactação (MEDINI) sobre a produção de leite no pico de lactação $(\mathrm{Kg})$ dos animais primíparos.

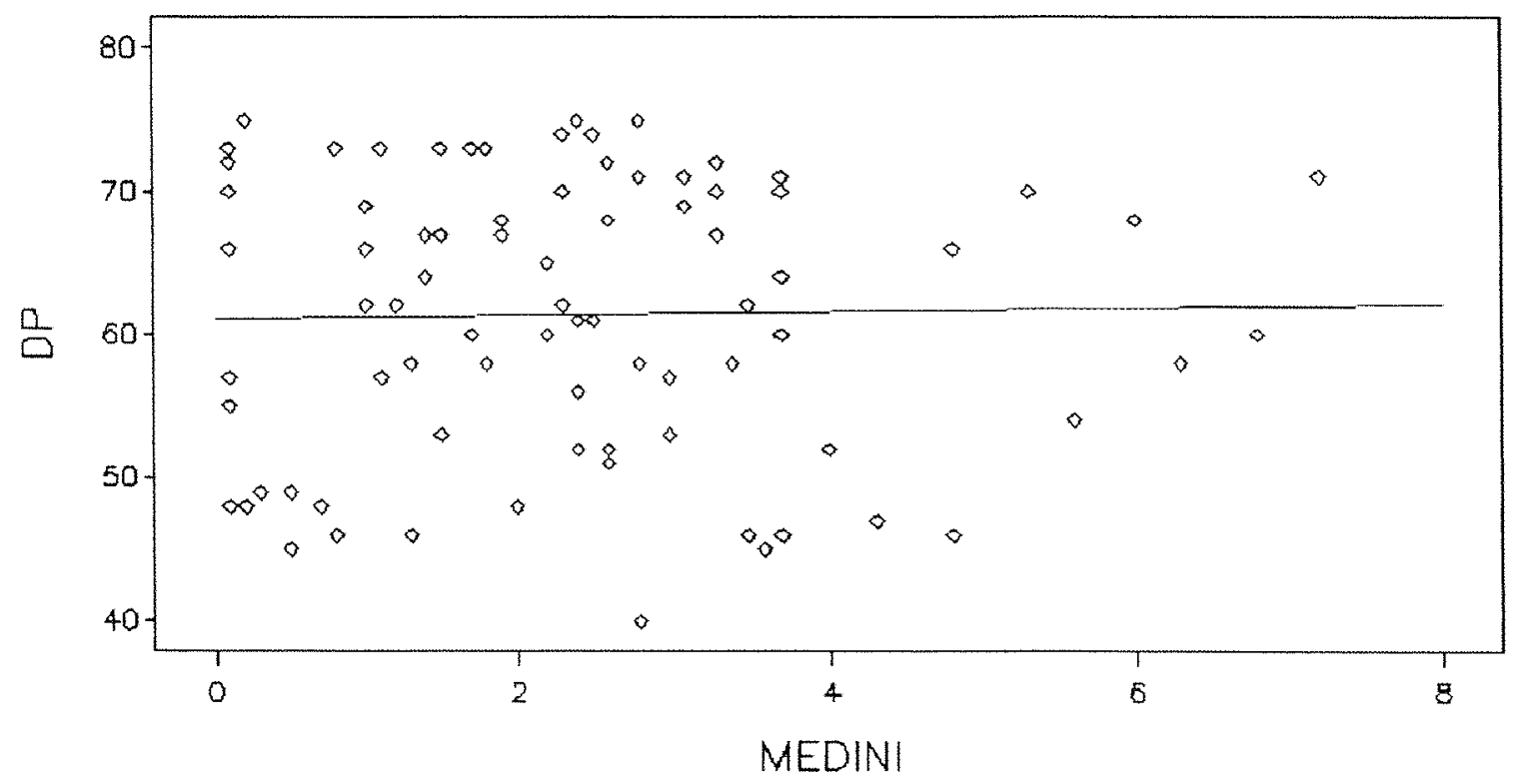

Figura 12. Efeito do EL médio do início da lactação (MEDINI) sobre a data de ocorrência do pico de lactação (dias) dos animais primíparos. 


\subsection{Multiparas}

Inicialmente foi realizada a análise de variância estudando-se os efeitos do EL e número de lactações (NL) e interação entre estes dois fatores. No entanto, como nenhum parâmetro analisado apresentou efeito significativo da interação estudou-se estes fatores independentemente.

\subsubsection{Escore Linear}

O resumo da análise de regressão do efeito da média do escore linear sobre os parâmetros estudados se encontra na tabela 6 .

Tabela 6. Resumo da análise de regressão do efeito do escore linear médio da lactação sobre a produção de leite e gordura em 305 dias em lactação, sobre a duração da lactação, e efeito escore linear médio do início da lactação sobre a produção de leite no pico e a data do mesmo em multíparos.

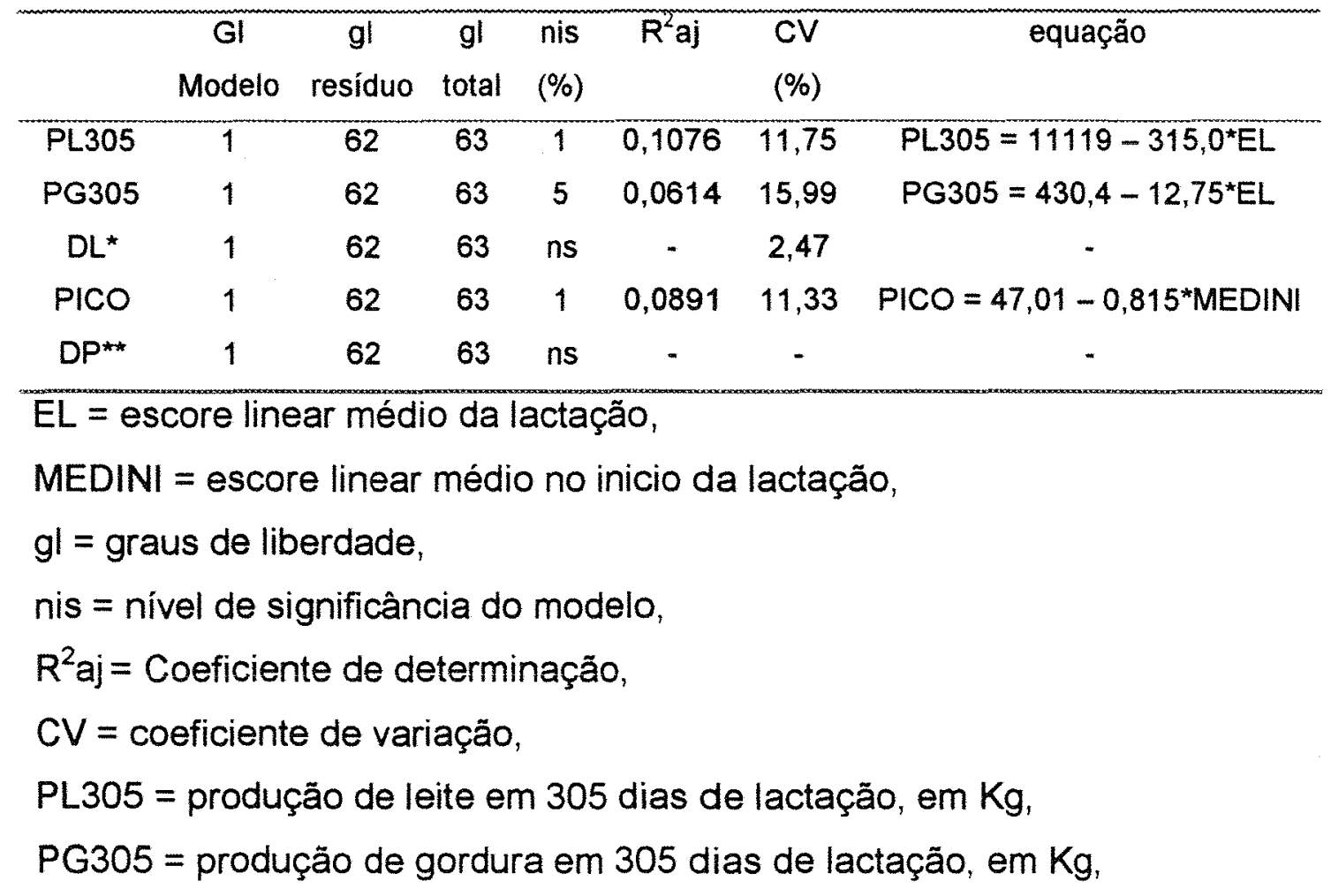


PICO = produção de leite no pico de lactação, em Kg,

$\mathrm{DL}=$ duração da lactação, em dias,

$\mathrm{DP}=$ data do pico de lactação, em dias.

* Transformado por indicação da análise de máxima verossimelhança para $\log _{10}$

* Transformado por indicação da análise de máxima verossimelhança para $1 / \mathrm{DP}$.

A produção de leite em 305 dias de lactação foi significativamente diminuída pelo aumento do escore linear médio e este efeito foi linear (figura 13). Estes achados são respaldados pela literatura (Raubertas \& Shook, 1982; Dabdoub \& Shook, 1984; Fetrow et al., 1988; Sender et al., 1996).

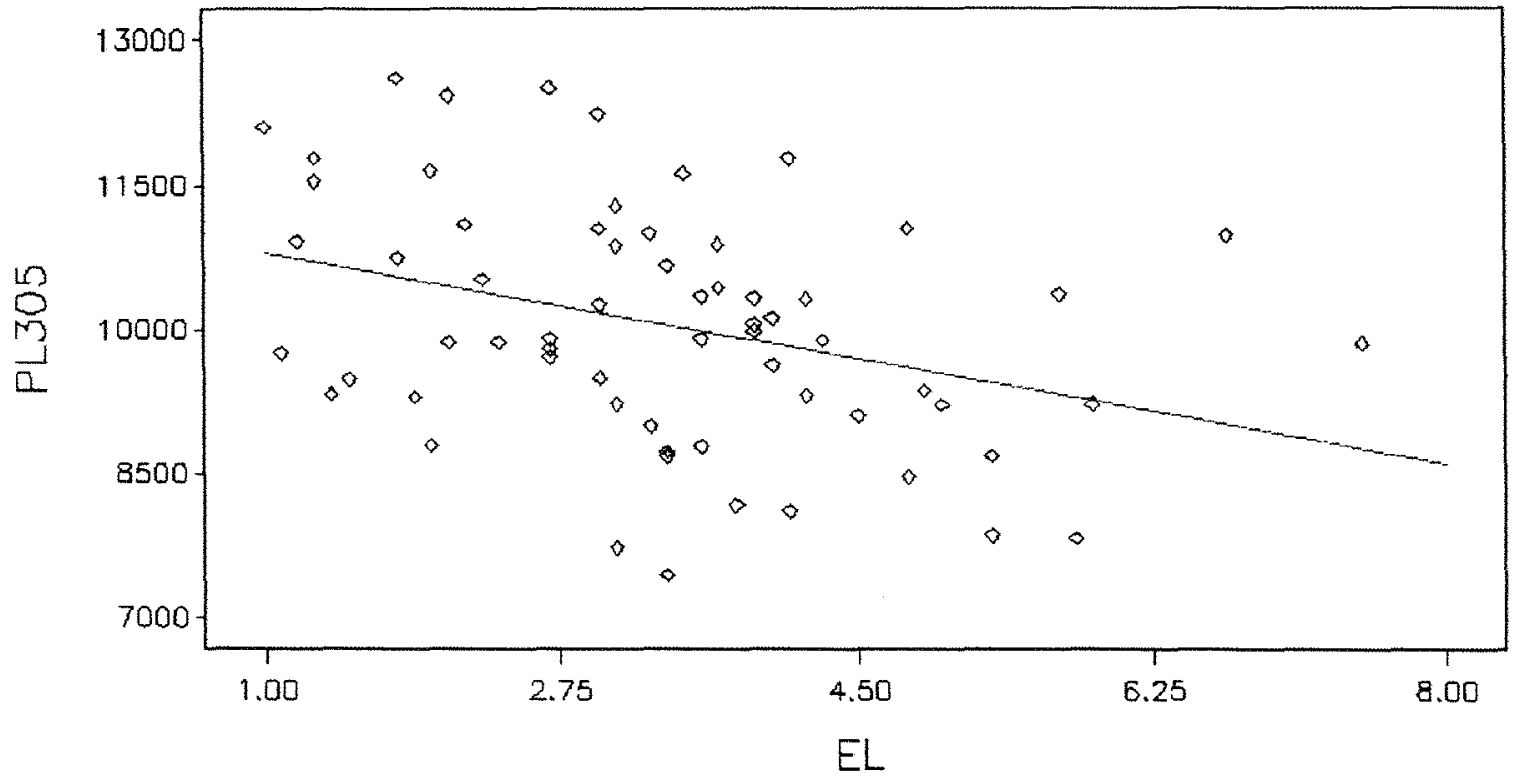

Figura 13 Produção de leite $(\mathrm{Kg})$ em 305 dias em lactação em função do escore linear médio da lactação (EL) dos animais multíparos.

A diminuição da produção de leite é devido a destruição do tecido secretor pela ação dos microrganismos na glândula mamária e pela migração de leucócitos para o seu interior (Philpot \& Nickerson, 1991). 
A comparação entre as perdas devido ao aumento do escore linear é dificultada devido a variação entre as metodologias utilizadas, no entanto Dabdoub \& Shook (1984), Reneau (1986) e Fetrow et al. (1988) utilizando o escore linear médio da lactação e a produção acumulada encontraram as seguintes perdas: 146 a $213 \mathrm{Kg}, 181 \mathrm{Kg}$ e $190 \mathrm{Kg}$ de leite.

Os autores citados acima não apresentam a produção média dos animais estudados, mas devido ao alto nível de produção dos animais deste trabalho é possivel supor que a maior perda associada ao aumento do EL médio da lactação encontrada no presente trabalho $(315 \mathrm{Kg})$ seja devido ao maior potencial de produção dos animais.

O coeficiente de determinação encontrado mostra que $10,8 \%$ da variação da produção de leite pode ser explicada pelo escore linear, sendo outros fatores não modelados responsáveis pelo resto da variação.

A análise de regressão indicou efeito significativo do $E L$ sobre a produção de gordura (tabela 6 e figura 14). Outros autores apresentaram redução da produção de gordura relacionada com o aumento da CCS (Kennedy et al., 1982; Gadini et al., 1997b; Norman et al., 1999).

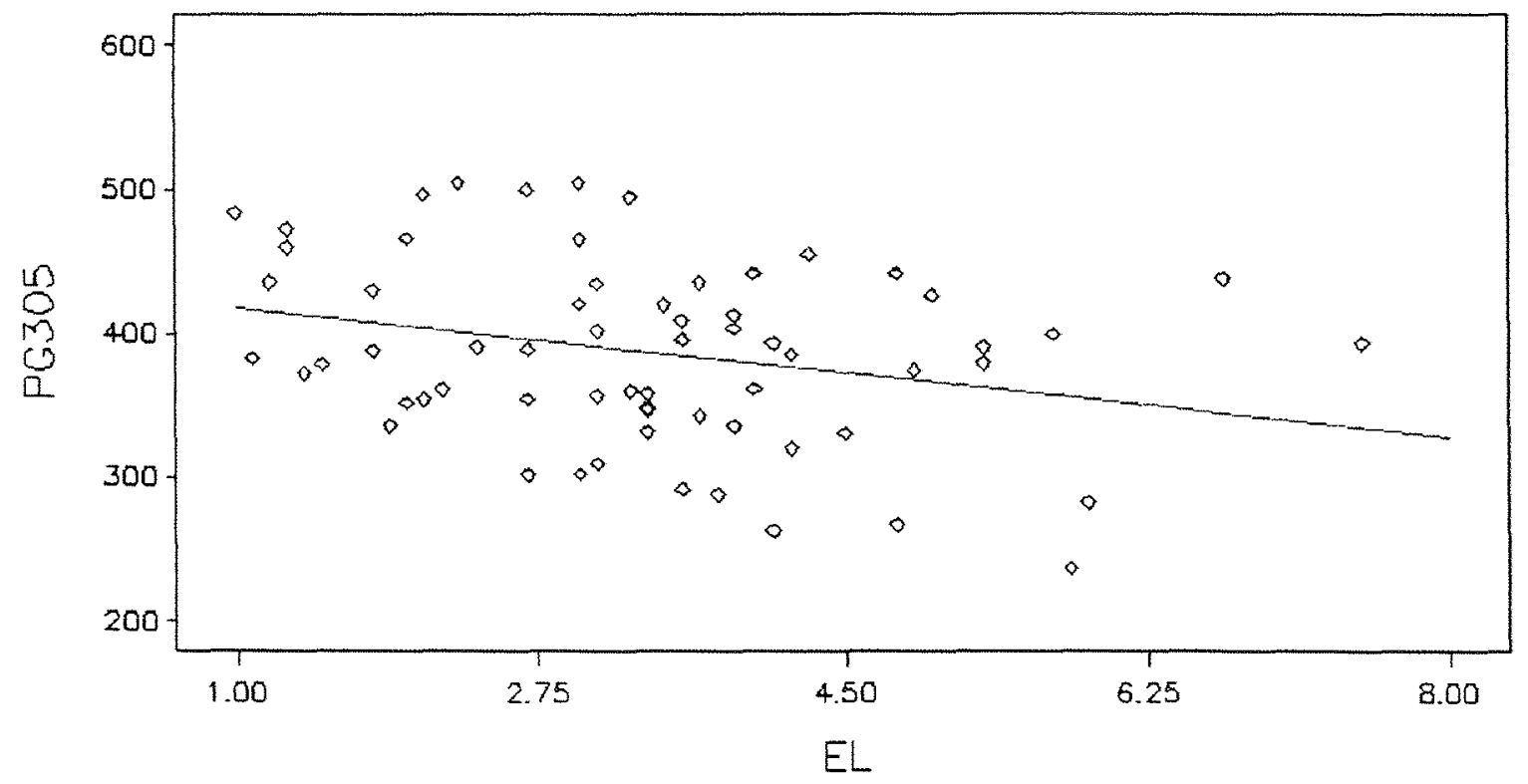

Figura 14. Produção de gordura $(\mathrm{Kg})$ em 305 dias em lactação em função do 
escore linear médio da lactação (EL) dos animais multíparos.

A redução da produção deste componente é devida aos mesmos fatores da redução de produção do leite. Assim como na produção de leite a produção de gordura é grandemente afetada por outros fatores não modelados neste trabalho; desse modo o coeficiente de determinação encontrado $(6,1 \%)$ é bastante baixo.

A variabilidade da produção de leite encontrada foi $26,5 \%$ menor que a variabilidade da produção de gordura.

Os dados de duração da lactação (DL) foram transformados para a função $\log _{10}$ para poderem ser modelados. A função de transformação foi indicada por análise de máxima verossimilhança do pacote estatístico SAS e diminuiu a variabilidade dos dados.

Apesar de aparente diminuição da duração da lactação relacionada ao aumento do escore linear médio da lactação esta não foi significativa (tabela 6 e figura 15).

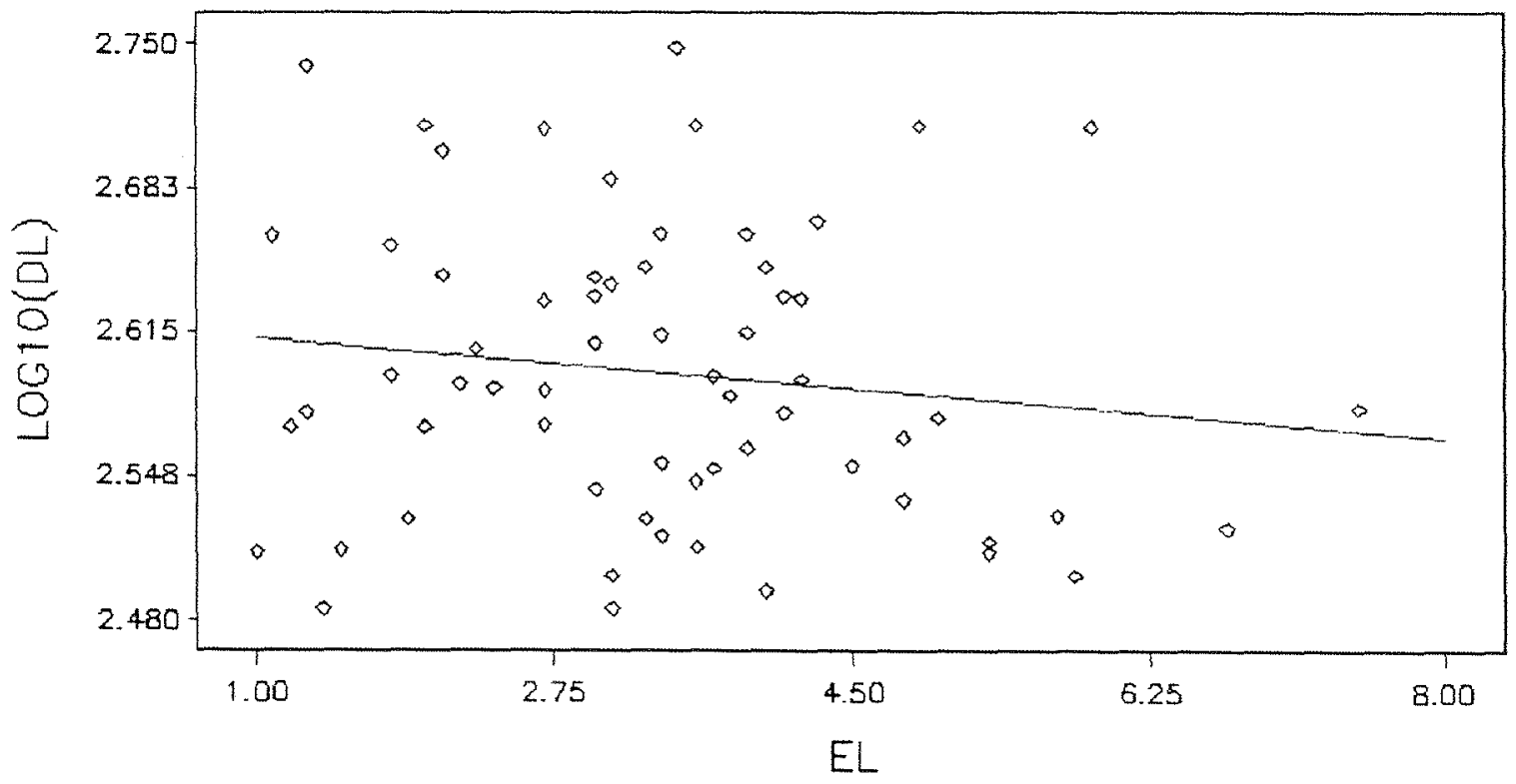

Figura 15. Duração da em lactação (transformado para $\log _{10}$ ) em função do escore linear médio da lactação (EL) dos animais multíparos. 
Provavelmente a existência de 2 animais com EL relativamente alto (cerca de 5 e 6) e lactações longas levaram a não significancia do efeito.

Machado et al. (1993) observaram redução significativa da duração da lactação associada a ocorrência da mastite.

A redução da duração da lactação pode ser explicada pela diminuição da produção de leite. Segundo Grôhn (1998), animais com mastite tem maior chance de serem descartados.

Além disso animais no fim da lactação que apresentam alta CCS podem ser secos para serem tratados, levando assim a diminuição da duração da lactação.

A variabilidade da duração da lactação foi reduzida a $15 \%$ da original pela transformação dos dados, melhorando sua distribuição em torno da reta.

A produção de leite no pico foi afetada pelo escore linear no início da lactação (MEDINI) levando a diminuição da mesma (tabela 6 e figura 16)

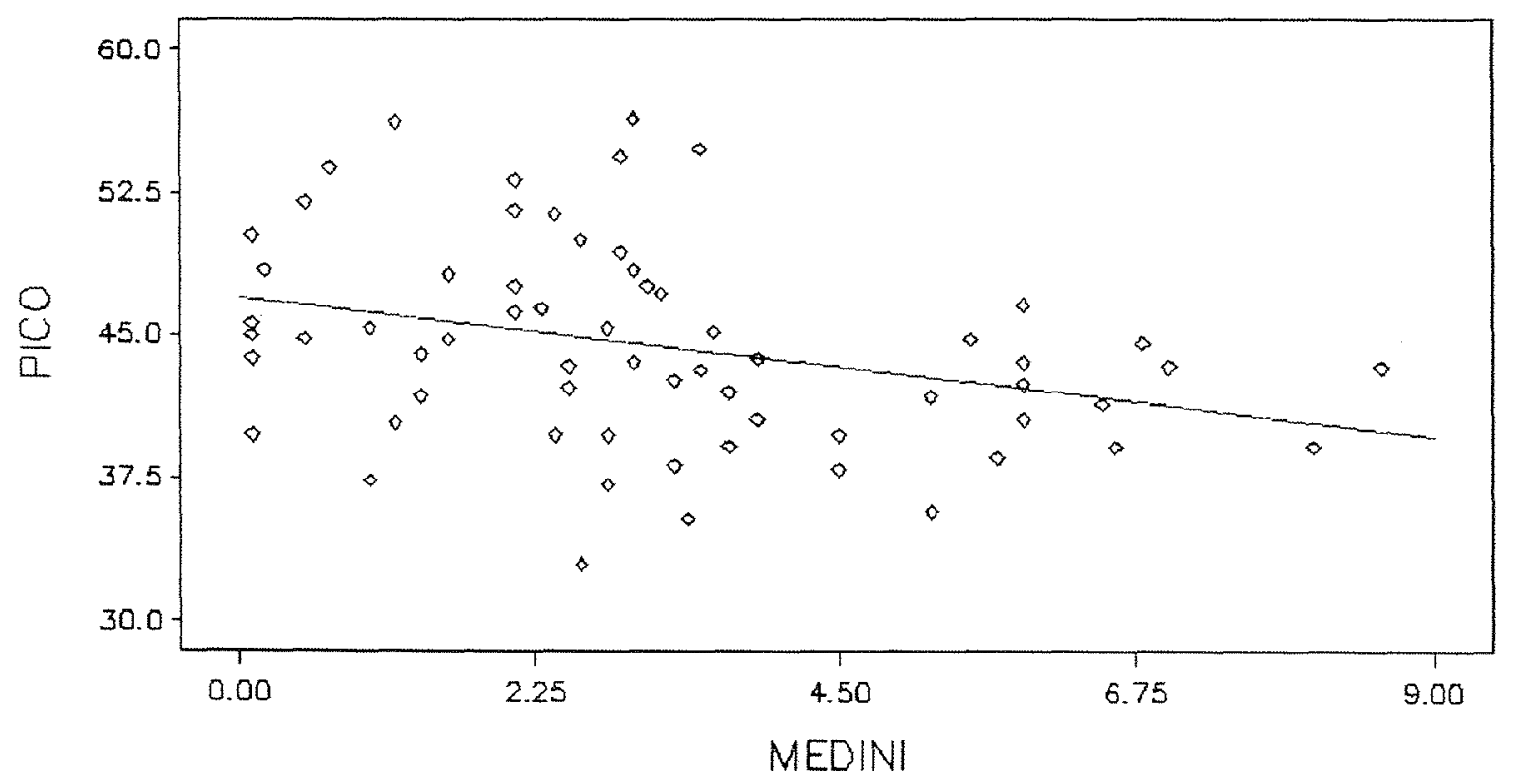

Figura 16. Produção de leite no pico em função do escore linear médio do início da lactação dos animais multíparos. 
O coeficiente de determinação deste parâmetro também foi muito baixo uma vez que apenas $8,9 \%$ da variação da produção no pico pode ser explicado pela média do escore linear no início da lactação.

A data de ocorrência do pico de produção, apesar de aparente efeito, não foi afetada pela média do escore linear no início da lactação (tabela 6 e figura 17).

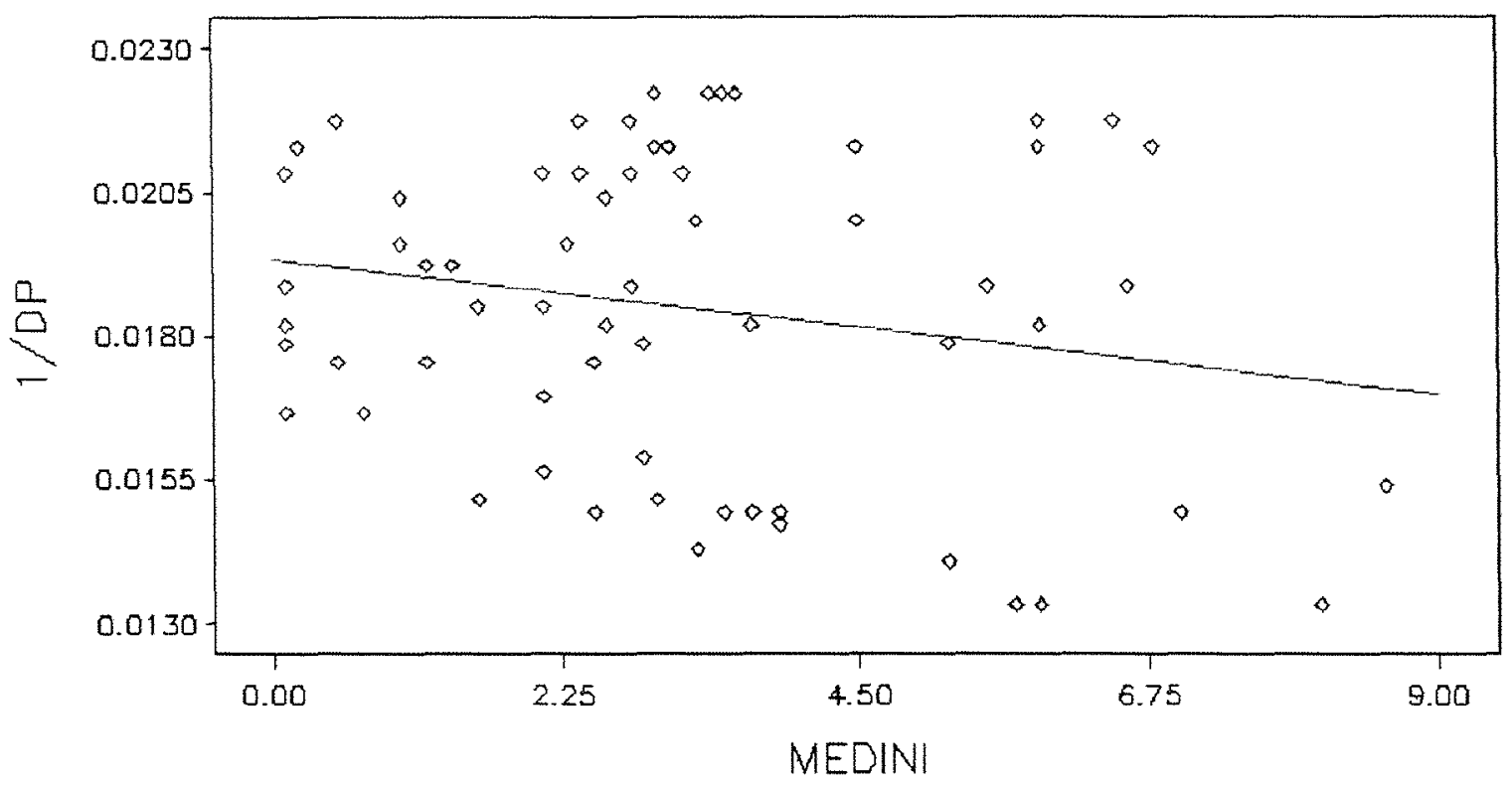

Figura 17. Data de ocorrência do pico de produção (transformada para seu inverso) em função do escore linear médio do início da lactação dos animais multíparos.

\subsubsection{Número de lactações}

Como a análise de variância indicou efeito significativo do número de lactações (NL) sobre a produção de leite, mesmo não sendo este o objetivo do trabalho, se estudou este efeito.

A produção de leite em 305 dias de lactação e no pico foram afetadas pelo número de lactações dos animais (Tabela 7). 
Tabela 7. Resumo da análise de variância do efeito do número de lactações sobre a produção de leite em 305 dias em lactação, e sobre a produção de leite no pico em multíparos.

\begin{tabular}{lcccccc}
\hline & $\begin{array}{c}\text { gl } \\
\text { modelo }\end{array}$ & $\begin{array}{c}\mathrm{gl} \\
\text { resíduo }\end{array}$ & $\begin{array}{c}\text { gl } \\
\text { total }\end{array}$ & $\begin{array}{c}\text { nis } \\
(\%)\end{array}$ & R'aj & CV (\%) \\
\hline PL305 & 3 & 60 & 63 & 5 & 0,0782 & 11,94 \\
PICO & 3 & 60 & 63 & 5 & 0,0996 & 11,26 \\
\hline gl = graus de liberdade, & & & & \\
nis = nível de significância do modelo, \\
$\mathrm{R}^{2}$ aj = Coeficiente de determinação, \\
CV = coeficiente de variação, \\
PL305 = produção de leite em 305 dias de lactação, em Kg, \\
PICO = produção de leite no pico de lactação, em $\mathrm{Kg}$.
\end{tabular}

A produção em 305 dias de lactação máxima foi obtida nos animais de quarta lactação que diferiram estatísticamente dos de segunda, no entanto, ambos não diferiram dos animais de terceira e quinta lactação (figura 18).

Freitas et al. (1980) também encontraram aumento da produção de leite até a quarta cria e descréscimo da produção a seguir.

$\mathrm{O}$ aumento de produção que acompanha o aumento do número de crias do animal é devido a maturação do esqueleto e ao aumento do tamanho corporal que proporciona maior tamanho do trato digestivo e da glândula mamária, permitindo assim maior consumo de alimentos e produção de leite (Schimidt, 1972; Anderson, 1985). 


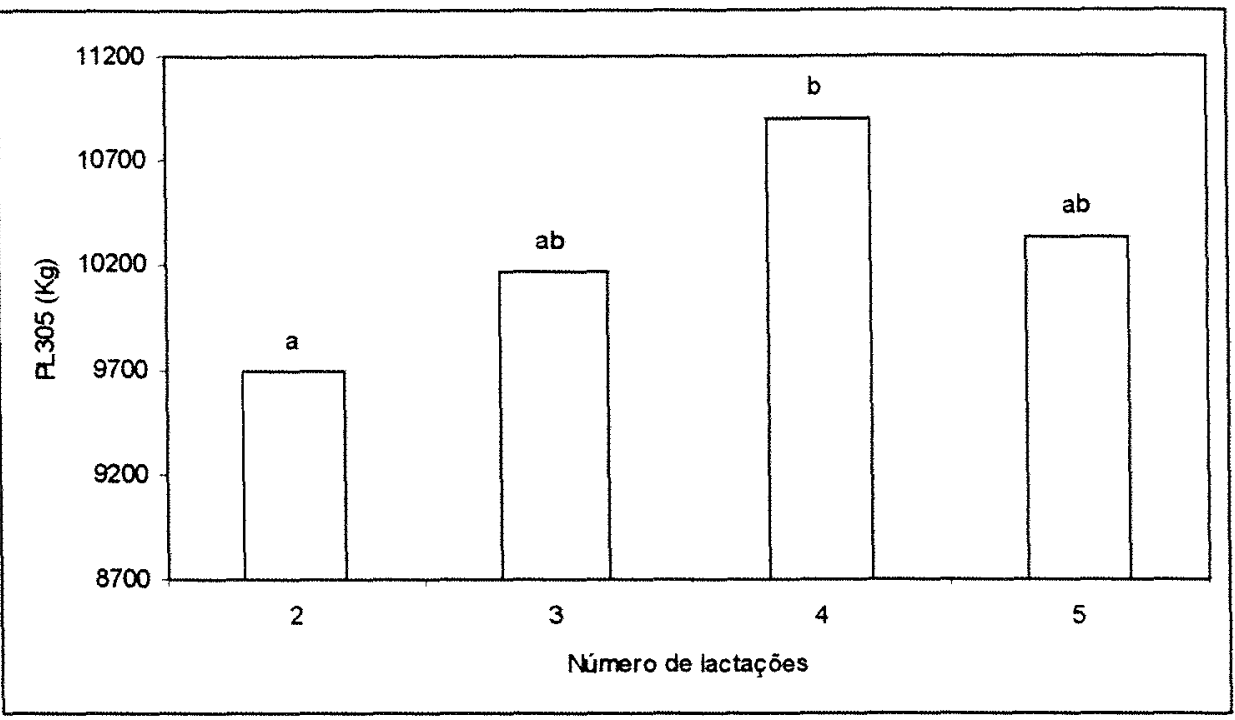

Figura 18. Produção de leite em 305 dias de lactação em função do número de lactações dos animais multíparos.

A produção máxima no pico de produção foi obtida na terceira lactação, que se diferenciou da segunda lactação. As quarta e quinta lactações não se diferenciaram das demais.

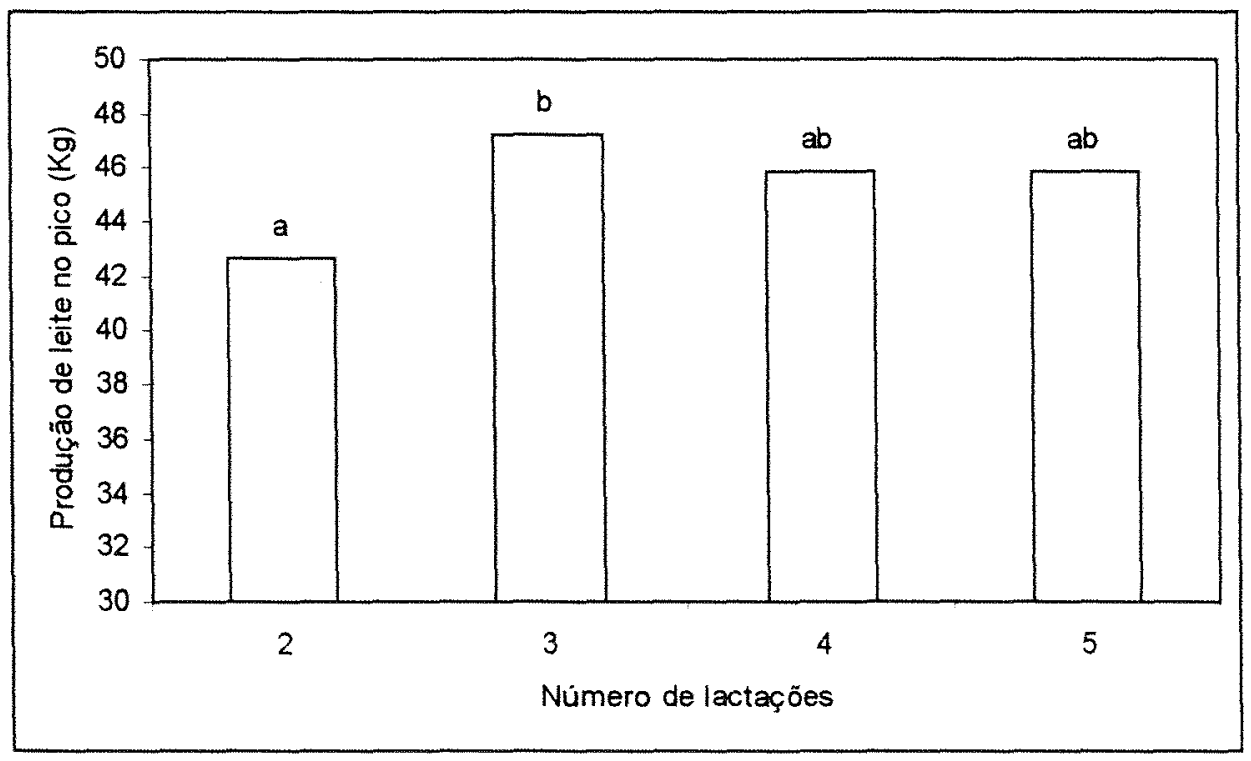

Figura 19. Produção de leite no pico de lactação em função do número de lactações dos animais multíparos. 


\section{CONCLUSÃO}

Comprovou-se e quantificou-se o efeito negativo do nível de células somáticas, transformado para escore linear, sobre a produção de leite e gordura em 305 dias de lactação e sobre a produção de leite no pico da lactação de bovinos da raça holandesa.

Considerando-se que os rebanhos analisados pelo Laboratório de Fisiologia da Lactação apresentam, em média, 121 vacas em lactação a redução de apenas uma unidade de EL corresponderia a um aumento de 38115 $\mathrm{Kg}$ de leite e $1543 \mathrm{Kg}$ de gordura em 305 dias de lactação para cada rebanho.

Desse modo fica realçada a importância da prevenção e combate a mastite. 


\section{REFERÊNCIAS BIBLIOGRÁFICAS}

AMARAL, L.A. Aspectos epidemiológicos da mastite bovina. In: ENCONTRO DE PESQUISADORES EM MASTITES, III, Botucatu, 1999. Anais. Botucatu: FMVZ-UNESP, 1999. p.19-26.

ANDERSON, R.R. Mammary gland. In: LARSON, B.L. (Ed.) Lactation. Ames: The Iwoa State University Press, 1985. cap.1, p.3-38.

BARBOSA, S.B.P. Estudo de características produtivas em rebanhos holandeses na bacia leiteira do estado de Pernambuco. Viçosa, 1990. 121p. Tese (Doutorado) - Universidade Federal de Viçosa.

BARTLETT, P.C.; MILLER, G.Y.; ANDERSON, C.R.; KIRK, J.H. Milk production and somatic cell count in Michigan dairy herds. Journal of Dairy Science, v. 73, n.10 p. $2794-2800,1990$.

BLOOD, D.C.; RADOTITIS, O.M. Veterinary medicine: a textbook of the diseases of cattle, sheep, pigs, goats and horses. Londres: Bailliere Tindall, 1989. 1502p.

CLEM, L.W.; MILLER, N.W.; BLY, J.E. Evolution of lymphocyte subpopulations, their interactions, and temperature sensitivities. In: WARR, G. W.; COHEN, N. Philogenesis of Immune Functions. Boca Raton: CRC Press, 1991. Cap.10, p.192-213. 
DABDOUB, S.A.M.; SHOOK, G.E. Phenotypic relations among milk yeld, somatic cell count, and clinical mastitis. Journal of Dairy Science, v.67, supl.1, p.163-164, 1984.

DALEY, M.J.; COYLE, P.A.; WILLIANS, T.J.; et al. Staphylococcus aureus mastitis: pathogenesis and treatment with bovine interleukin-1 $\beta$ e interleukin2. Journal of Dairy Science, v.74, n.12, p.4413-4424, 1991.

DANIEL, L.R.; CHEW,B.P.; TANAKA,T.S.; TJOELKER,L.W. In Vitro effects of $\beta$-carotene and vitamin $A$ on peripartum bovine peripheral blood mononuclear cell proliferation. Journal of Dairy Science, v.74, n.3, p.911915, 1991.

D'ARCE, R.D.; FLECHTMANN, C.H.W. Introdução a anatomia e fisiologia animal. São Paulo: Nobel, 1980. 186p.

DARNELL, J.; LODISH, H.; BALTIMORE, D. Molecular cell biology. 2 ed. New York: Scientific American Books Inc., 1990. 1105p.

ERSKINE, R.J.; BARTLETT, P.C.; TAVERNIER, S.R.; FOWLER, L.H.; WALKER, R.D.; SEGUIN, J.H.; SHESTER, D. Recombinant bovine interleukin-2 and dry cow therapy: Efficacy to cure and prevent intramammary infections, safety, and effect on gestation. Journal of Dairy Science, v.81, n.1, p.107-115, 1998.

FERRI, R.G.; CALICH, V.L.G.; VAZ, C.A.C. Imunologia. 2 ed. São Paulo: Artes Médicas, 1979. 317p.

FETROW, J.; ANDERSON, K.; SEXTON, S.; BUTCHER, K. Herd composite somatic cell counts: averege linear score and weighted averege somatic cell 
score and milk production. Journal of Dairy Science, v.71, n.1, p.257-260, 1988.

FREITAS, M.A.R.; LOBO, R.B.; DUARTE, F.A.M.; NAUFEL, F. Informações sobre aspectos da produção em um rebanho de raça holandesa. In: REUNIÄO ANUAL DA SOCIEDADE BRASILEIRA DE ZOOTECNIA, XVII, Fortaleza, 1980. Anais. Fortaleza: SBZ, 1980. p.181-182.

FUENTE, L.F. de la; PRIMITIVO, F.S.; FUERTES, J.A; GONZALO, C. Daily and between-milking variations and repeatabilities in milk yield, somatic cell count, fat and protein of dairy ewes. Small Ruminant Research, v.24, n.2, p.133-139, 1997

GADINI, C.H.; KEOWN, J.F.; VLECK, L.D.V. Parâmetros genéticos do escore de células somáticas. In: Reunião Anual da SBZ, XXXIV; Juiz de Fora, 1997a. Anais. Juiz de Fora: SBZ, 1997. v.3, p.41-43.

GADINI, C.H.; KEOWN, J.F.; VLECK, L.D.V. Parâmetros genéticos das produções de leite, gordura e proteína, e do escore de células somáticas em 305 dias de lactação. In: Reunião Anual da SBZ, XXXIV.; Juiz de Fora, 1997b. Anais. Juiz de Fora: SBZ, 1997. v.3, p.47-49.

GIRAUDO, J.A.; CALZOLARI, A.; RAMPONE, H.; RAMPONE, A.; GIRAUDO, A.T.; BOGNI, C.; LARRIESTRA, A.; NAGEL, R. Field trials of vaccine against bovine mastitis. 1. Evaluation in heifers. Journal of Dairy Science, v.80, n.5, p.845-853, 1997.

GIRAUDO,J.A. Conceptos basicos sobre inmunologia de la glandula mamaria y utilizacion de vacunas contra mastitis. In: Encontro de Pesquisadores em Mastite Bovina do Estado de São Paulo, 2, Nova Odessa, 1996. Palestras. 
Nova Odessa: Instituto de Zootecnia, 1996, p.73-86.

GRAAFA, T.; DWINGERB, R.H. Estimation of milk production losses due to sub-clinical mastitis in dairy cattle in Costa Rica. Preventive Veterinary Medicine, v.26, n.3-4, p.215-222, 1996. I Resumo em CAB Abstracts on CD-ROM, 1996-1998/07

GRÔHN, Y.T. Studies examine possibility of milk yield, disease link. Feedstuffs, v.70, n.10, p.13-28, 1998.

GUIDRY, A.J. Mastitis and the immune system of the mammary gland. In: LARSON, B.L. (Ed.) Lactation. Ames: The Iwoa State University Press, 1985. cap.7, p.299-262.

GUYTONN, A.C. Tratado de fisiologia médica. Rio de Janeiro: Ed. Guanabara Koogan S.A., 1992. 864p.

HABEL, R.E. Sistema digestivo do ruminante. In: GETTI, R. SISSON/GROSMAN - Anatomia do animais domésticos. 5 ed. Rio de Janeiro: Ed. Guanabara Koogan S. A., 1986. cap.29, p.807-858.

HARGROVE, G.L. Bias in composite milk samples with unequal milking intervals. Journal of Dairy Science, v.77, n.7, p.1917-1921, 1994.

HARMON, R.J. Fatores que afetam a contagem de células somáticas. In: Simpósio Internacional sobre Qualidade do Leite, 1.; Curitiba, 1998. Anais. Curitiba: UFPR, 1998. p.7-15.

HARMON, R.J. Physiology of mastitis and factors affecting somatic cell counts. Journal of Dairy Science, v.77, n.7, p.2103-2112, 1994. 
HORNET, P.; BEAUDEAU, F.; SEEGERS, H.; FOURICHON, C. Reduction in milk yield associated with somatic cell counts up to 600000 cells $/ \mathrm{ml}$ in french Holsteins cows without clinical mastitis. Livestock Production Science, v.61, n.1, p.33-42, 1999.

JAIN, N.C. Common mammary pathogens and factors in infection and mastitis. Journal of Dairy Science, v.62, n.1, p.128-134, 1979.

KAABI, M.; ABROUG, B.; ANEL, L.; ALVAREZ, M.; ANEL, E.; DE LA FUENTE, F.; HAMOUDA, M.B.; ROUSSINI, H. Estimación de algunos factores de variación de la producción lechera del ganado vacuno en el norte de Túnez. ITEA, v.20, n.2, p.780-782, 1999.

KEHRLI Jr., M.E.; CULLOR, J.S.; NICKERSON, S.C. Immunobiology of hematopoietic colony-stimulating factors: Potencial application to disease prevention in the bovine. Journal of Dairy Science, v.74, n.12, p.43994412, 1991.

KENNEDY, B.W.; SETHAR, M.S.; MOXLEY, J.E.; DOWNEY, B.R. Heritability of somatic cell counts and its relationship with milk yield and composition in Holsteins. Journal of Dairy Science, v.65, n.5, p.843-847, 1982.

KIRK, J.H. Programmable calculator program for linear somatic cell scores to estimate mastitis yield losses. Journal of Dairy Research, v. $67, n .2$, p.441$443,1984$.

LAEVENS, H.; DELUYKER, H.; SCHUKKEN, Y.H.; MEULEMEESTER, L.D.; VANDERMEERSCH, R.; MUÉLENAERE, E.D.; KRUIF, A.D. Influence of parity and stage of lactation on the somatic cell count in bacteriologically 
negative dairy cows. Journal of Dairy Science, v.80, n.12, p.3219-3226, 1997.

LANGENEGGER, J.; COELHO, N.M.; LANGENEGGER, C.H.; CASTRO, R.P. de. Estudo da incidência da mastite bovina na bacia leiteira do Rio de Janeiro. Pesquisa Agropecuária Brasileira, v.5, n p.437-440, 1970.

LARANJA, L.F.; MACHADO, P.F. Ocorrência de mastite bovina em fazendas produtoras de leite B no estado de São Paulo. Scientia Agricola, v.51, n.3, p.578-585, 1994.

LESCOURRET, F; COULON, J.B. Modelling de impact of mastitis on milk production by dairy cows. Journal of Dairy Science, v.77, n.8, p.2289$2301,1994$.

MACHADO, P.F. BARANCELLI, G., PEREIRA, A.R. CCS: Leite com Mais Qualidade e Melhor Rendimento Industrial. Indústria de Laticínios, ano 2, n. 13, p. $65-68,1998$.

MACHADO, P.F.; PEREIRA, A.R.; SARRÍES, G.A. Efeitos da contagem de células somáticas na qualidade do leite e a atual situação de rebanhos brasileiros. Revista do Instituto de Laticínios "Cândido Tostes", v.54, n.309, p.10-16, 1999.

MACHADO, S.G.; CARDOSO, V.L; SILVA, A.M.S.; FREITAS, M.A.R. Influência da ocorrência da mastite na produção de leite e duração da lactação. In: REUNIÃO ANUAL DA SOCIEDADE BRASILEIRA DE ZOOTECNIA, XXX, Rio de Janeiro, 1993. Anais. Rio de Janeiro: SBZ, 1993. p.587.

MILLER, R.H.; PAAPE, M.J.; FULTON, L.A.; SCHUTZ, M.M. The relationship of 
milk somatic cell count to milk yields for Holteins heifers after first calving. Journal of Dairy Science, v.76, n.3, p.728-733, 1993.

MORIN, D.E.; PETERSEN, G.C.; WHITMORE, H.L.; HUNGERFORD, L.L.; HINTON, R.A. Economic analysis of a mastitis monitoring and control program in four dairy herds. Journal of American Veterinary Medical Association, v.202, n.4, p.540-548, 1993.

NADER FILHO, A.; SCHOCKEN-ITURRINO, R.P.; ROSSI JUNIOR, O.D. CEMBRANELLI, E.M. Prevalência e etiologia da mastite bovina na região de Ribeirão Preto. Pesquisa Veterinária Brasileira, v.5, n.2, p.53-56, 1985.

NEAVE, F.K.; DODD, F.H.; KINGWILL, R.G.; WESTGARTH, D.R. Control of mastitis in the dairy herd by hygiene and manegement. Journal of Dairy Science, v.52, n.5, p.696-707, 1969.

NICKERSON, S.C. Immune mechanisms of the bovine udder: An overview. Journal of American Veterinary Medical Association, v.187, n.1, p.41-45, 1985.

NORMAN, H.D.; VANRADEN, P.M.; WRIGHT, J.R.; SMITH, L.A. Mathematical representations of correlations among yield traits and somatic cell score on test day. Journal of Dairy Science, v.82, n.10, p.2205-2211, 1999.

PAAPE, M.J.; GUIDRY, A.J.; JAIN, N.C.; MILLER, R.H. Leukocytic defense mechanisms in the udder. Flem. Vet. J., v.62, supl. 1, p.95-109, 1991. /Disponivel na Internet (http://mpps.rug.ac.be/contents.html). consultado em março de 1999. 
PAAPE,M.J.; SCHULTZE, W.D.; MILLER, R.H.; SMITH, J.W. Thermal stress and circulating erythrocytes, leukocytes, and milk somatic cells. Journal of Dairy Science, v.56, n.1, p.84-91, 1973.

PAAPE, M.J.; WERGIN, W.P.; GUIDRY, A.J.; PEARSON, R.E. Leukocytessecond line of defense against invading mastitis pathogens. Journal of Dairy Science, v. 62, n.1, p.135-153, 1979.

PARK, C.S.; JACOBSON, N. Glândula mamária e lactação. In: SWENSON, M. J.; REECE, W.O. Dukes - Fisiologia dos animais domésticos. 11 ed. Rio de Janeiro: Ed. Guanabara Koogan LTDA, 1996. cap. 37, p.645-659.

PARK, Y.H.; HAMILTON, M.J.; DAVIS, W.C. Bovine mononuclear leukocyte subpopulations in peripheral blood and mammary gland secretions during lactation. Journal of Dairy Science, v.75, n.4, p.998-1006, 1992.

PELCZAR, M.J.; CHAN, E.C.S.; KRIEG, N.R.; EDWARDS, D.D.; PELCZAR, M.F. Microbiologia - Conceitos e aplicaçōes. Vol. II. 2 ed. São Paulo: Makron Books do brasil Ed. LTDA., 1996. 517p.

PHILPOT, W.N.; NICKERSON, S.C. Mastitis: Counter Attack. Naperville, EUA: Babson Bros.Co., 1991. 150 p.

PHILPOT, W.N. Control of mastitis by hygiene and therapy. Journal of Dairy Science, v.62, n.1, p.168-176, 1979.

PIMPÃO, C.T.; RIBAS, N.P.; MONARDES, H.; ALMEIDA, R. de. Estudo dos efeitos do meio ambiente sobre as características produtivas de vacas da raça holandesa da região de Arapoti, Estado do Paraná. Revista Brasileira de Zootecnia, v.26, n.3, p.494-500, 1997. 
POLITITIS, I.; HIDIROGLOU, M.; BATRA, T.R.; GILMORE, J.A.; GOREWIT, R.C.; SCHERF, H. Effects of vitamin $E$ on immune function of dairy cows American Journal of Veteriary Research, v.56, n.2, p.179-184, 1995.

PRYCE, J.E.; NIELSEN, B.L.; VEERKAMP, R.F.; SIMM, G. Genotype and feeding system effects and interactions for health and fertility traits in dairy cattle. Livestock Prodution Science, v.57, n.3, p.193-201, 1999.

RAUBERTAS, R.F.; SHOOK, G.E. Relationship between lactation measures of somatic cell concentration and milk yield. Journal of Dairy Science, v.65, n.3 p.419-425, Mar 1982.

REBHUN, W.C. Diseases of dairy cattle. Media: Williams \& Wilkins, 1995. $530 p$.

REIS, R.B.; SILVA, H.M. Influencia de alguns fatores do meio sobre as principais características produtivas em rebanhos holandeses. I - Produção de leite, produção de gordura, porcentagem de gordura. Arquivo Brasileiro de Medicina Veterinária e Zootecnia, v.39, n.2, p.273-290, 1987.

RENEAU, J.K. Effetive use of dairy herd improvement somatic cell count in mastitis control. Journal of Dairy Science, v 69, n 6, p.1708-1720, 1986.

RICHTER, G.O.; RIBAS, N.P; MONARDES, H.G.; ALMEIDA, R.; VEIGA, D.R. Estudo da produção de leite, produção de gordura e porcentagem de gordura em vacas da raça holandesa, região de Witmarsum, Palmeira, Paraná. Revista do Setor de Ciências Agrárias, v.14, n.1-2, p.141-149, 1995. 
SAMPAIO, I.B.M. Estatística Aplicada a Experimentação Animal. Belo Horizonte: Fundação de Ensino e Pesquisa em Medicina Veterinária e Zootecnia, 1998. 221 p.

SAS/STAT User's Guide Version 64 ed. Cary, SAS Institute Inc., 1990. 1022p.

SCHEPERS, A.J.; LAM, T.J.G.M.; SCHUKKEN, Y.H.; WILMINK, J.B.M.; HANEKAMP, W.J.A. Estimation of variance components for somatic cell counts to determine thresholds for uninfected quartes. Journal of Dairy Science, v.80, n.8, p.1833-1840, 1997.

SCHIMIDT, G. H. Biology of lactation. San Francisco: W. H. Freeman and Company, 1971. $317 p$.

SCHULTZ, M.M.; HANSEN, L.B.; STEUERNAGEL,G.R.; KUCK, A.L. Variation of milk, fat, protein, and somatic cells for dairy cattle. Journal of Dairy Science, v.73, n.2, p.484-493, 1990.

SENDER, G.; LUKASZEWICH, M.; ROSOCHOWICZ, L.; DORYNEK, Z. Economic value of somatic cell count with special emphasis to polish conditions. Stocarstvo, v.50, n.5, p.361-362, 1996. I Resumo em CAB Abstracts on CD-ROM, 1996-1998/07 /.

SHELDRAKE, R.F.; HOARE, R.J.T.; McGREGOR, G.D. Lactation stage, parity, and infection affecting somatic cells, eletrical conductivity, and serum albumin in milk. Journal of Dairy Science, v.66, n.3, p.542-547, 1983.

SORDILLO, L. M.; SHAFER-WEAVER, K; DeROSA, D. Immunobiology of the mammary gland. Journal of Dairy Science, v.80, n.8, p.1851-1865, 1997. 
TIZARD, I.R. Veterinary immunology: An introduction. 6 ed. Philadelphia: W. B. Saunders Company, 1996. 531p.

VASCONCELOS, C.G.C.; NADER FILHO, A.; AMARAL, L.A.; PEREIRA, G.T. Influência da estação do ano, do estádio de lactação e da hora da ordenha sobre o número de células somáticas do leite bovino. Arquivo Brasileiro de Medicina Veterinária e Zootecnia, v.49, n.4, p.483-491, 1997.

VENZKE, W.G. Timo. In: GETTI, R. SISSON/GROSMAN - Anatomia do animais domésticos. 5 ed. Rio de Janeiro: Ed. Guanabara Koogan S. A., 1986. cap.34, p.997.

VERHOEF, J. Modulation of Inflammation. Flem. Vet. J., v.62, supl. 1, p.153161, 1991. /Disponivel na Internet (http://mpps.rug.ac.be/contents.html) consultado em março de 1999.

WARR, G.W.; COHEN, N. Philogenesis of immune functions. Boca Raton: CRC Press, 1991. 326 p.

WILSON, D.J.; GONZALES, R.N.; DAS, H.H. Bovine mastitis phatogens in New York and Pennsylvania: Prevalence and Effects on Somatic Cell Count. Journal of Dairy Science, v.80, n.10, p.2592-2598, 1997. 


\section{APÊNDICE}

Resultado de cultura microbiológica de 93 amostras de leite colhidas em animais que apresentaram alteração da condutividade elétrica no rebanho (figura 20).

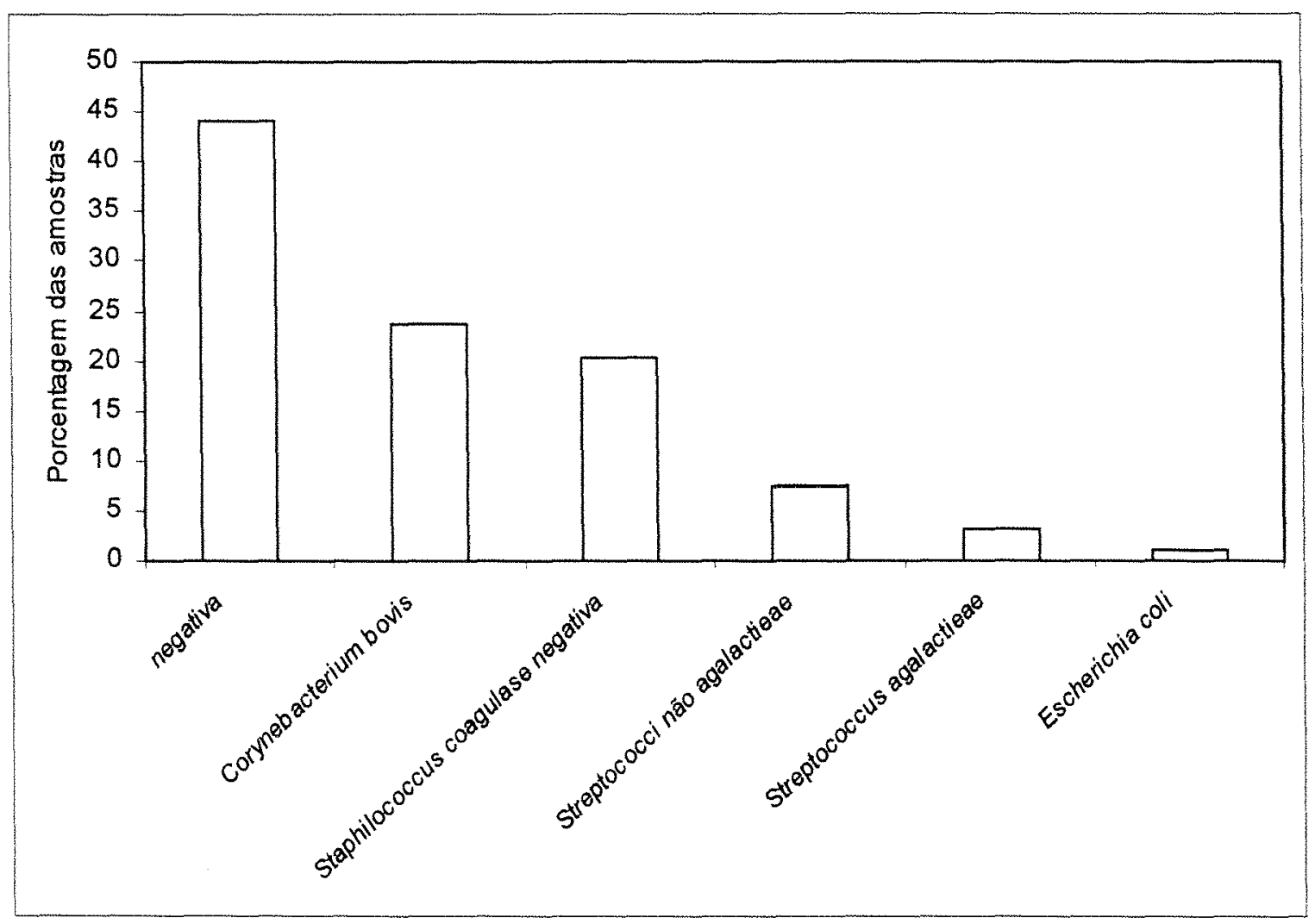

Figura 20. Resultado de cultura microbiológica de 93 amostras de leite colhidas em animais que apresentaram alteração da condutividade elétrica do leite. 